\title{
NOTES
}

\section{A PUBLIC GOODS APPROACH TO CALCULATING REASONABLE FEES UNDER ATTORNEY FEE SHIFTING STATUTES*}

\section{INTRODUCTION}

Commentators on statutory attorney fee shifting "rank among our most adept navel-gazers." 1 Indeed, the proliferation of literature examming attorney fee shifting statutes seems to be matched only by the proliferation of such statutes. ${ }^{2}$ A reasonable person therefore might read the title of this Note and ask, "Why more?" Justification for continued study stems from the complete lack of consensus on most major issues arising under such statutes and the increasing use of fee shifting to promote certain forms of civil action. ${ }^{3}$ One need look no further than the Supreme Court for evidence of this lack of consensus: in virtually every fee shifting case decided recently, the Court either has split five-to-four ${ }^{4}$ or has failed to muster a majority. ${ }^{5}$

* The author thanks Professor Jerome Culp for his helpful comments on earlier drafts of this Note. All errors in reasoning remain solely those of the author.

1. See generally Rodell, Goodbye to Law Reviews, 23 VA. L. REv. 38, 43 (1936) (criticizing all law review writers).

2. For a sampling of articles examining attorney fee shifting statutes, see note 14, infra. For a discussion of the number of statutes, see Percival \& Miller, The Role of Attorney Fee Shifting in Public Interest Litigation, LAW \& CONTEMP. Prons., Winter 1984, at 233 (number of federal statutes has topped 150).

3. See supra note 2 (150 federal statutes provide for fee shifting). The statutes include, e.g., Age Discrimination in Employment Act of 1967, 29 U.S.C. $\$ 626(b)$ (1982); Civil Rights Act of 1964, Title II, 42 U.S.C § 2000a-3(b) (1982); Fair Housing Act of 1968, 42 U.S.C § 3612(c) (-); Voting Rights Amendment of 1975, 42 U.S.C. $\S 1973 e e-4$ (c) (1982 \& Supp. V 1987).

4. See Hewitt v. Helms, 482 U.S. 755 (1987) (whether claiming "prevailing party" status, for purposes of attorney fee award under 42 U.S.C. $\S 1988$, party must receive at least some relief on merits of claim); City of Riverside v. Rivera, 477 U.S. 561 (1986) (whether courts can reasonably award fees significantly in excess of monetary damages); Hensley v. Eckerhart, 461 U.S. 424 (1983) (whether the "extent of success" in litigation should be considered in determining amount of attorney fees awarded); see also Missouri v. Jenkins, 109 S. Ct. 2463 (1989) (five-to-three split on issue of enhancement of fee award against state on basis of delay in payment).

5. See Pennsylvania v. Delaware Valley Citizens' Council for Clean Air, 483 U.S. 711 (1987) [hereinafter Delaware Valley II] (split four-to-one-to-four on whether enhancement of lodestar to compensate attorney for assuming risk of loss is impermissible under fee-shifting statutes). 
A particularly troublesome issue for courts has been shaping a workable standard to meet the statutorily undefined requirement that the amount of a fee award be "reasonable." The Supreme Court has muddled through this problem of standard setting with a lack of consensus and clarity ${ }^{7}$ while lower courts have struggled to apply the Court's decisions, ${ }^{8}$ and commentators have tried to make sense of the judicial morass. ${ }^{9}$ As a result, many civil rights cases ${ }^{10}$ today mvolve two distmct steps: (1) a determmation of the substantive rights imvolved, ${ }^{11}$ and (2) a protracted dispute over the "reasonableness" of attorney's fees for the prevailing party. ${ }^{12}$ The definition of a reasonable fee serves as the subject not only of this Note, but also of countless other judicial opinions ${ }^{13}$ and scholarly articles. ${ }^{14}$ This Note, however, differs from prior investigations of the fee problem to the extent that it advocates a public goods mechanism to determine reasonableness.

This Note argues that, at least in the civil rights context, most courts and commentators have forgotten the general purpose of fee shift-

6. 42 U.S.C. $\S 1988$ (1982) ("In any action or proceeding to enforce a provision of [various civil rights statutes], the court in its discretion, may allow the prevailing party, other than the United States, a reasonable attorney's fee as part of the costs.").

7. See National ass'N of Attorneys General, Report to the Congress: Civil RIGHTS ATTORNEY's FEES ACT OF 1976, at 27-30 (1984) (finding that judiciary has failed to set meaningful standards for determining what constitutes a reasonable attorney's fee and recommending Congress set maximum of $\$ 75$ per hour).

8. See infra notes 31,34 and accompanying text.

9. See infra note 14 (current scholarly analysis on attorney fee shifting).

10. The term "civil rights" is used somewhat loosely in this Note, but generally refers to those rights protected by 42 U.S.C. $\S \S 1981$ (employment discrimination and admissions policies), 1982 (discriminatory property transactions), 1983 (all official discrimination including racial segregation and infringements of first amendment rights), 1985 (conspiracies to deny equal protection), and 1986 (same) (1982).

11. See, eg., Save Our Cumberland Mountains, Inc. v. Hodel, 651 F. Supp. 1528, 1531 (D.D.C. 1986) (noting that litigation involving substantive issues ended in settlement in 1985) aff' $d$ in part and rev'd in part, 826 F.2d 43 (D.C. Cir. 1987), vacated in part on reh'g, 857 F.2d 1516 (D.C. Cir. 1988) (en banc).

12. See, e.g., Cumberland Mountains, 857 F.2d at 1525 (D.C. Cir. 1988) (en banc) (noting that since 1985 litigation has been limited to attorneys fees).

13. See, e.g., Delaware Valley II, 483 U.S. at 711; Pennsylvania v. Delaware Valley Citizens' Council for Clean Air, 478 U.S. 546 (1986) [hereinafter Delaware Valley ]; Blum v. Stenson, 465 U.S. 886 (1984); Hensley v. Eckerhart, 461 U.S. 424 (1983); McKenzie v. Kennickell, (No. 88-5155) (D.C. Cir. May 23, 1989); Save Our Cumberland Mountains, Inc. v. Hodel, 857 F.2d 1516 (D.C. Cir. 1988) (en banc); Lindy Bros. Builders v. American Radiator \& Standard Sanitary Corp., 487 F.2d 161 (3d Cir. 1973).

14. See, e.g., Berger, Court Awarded Attorneys' Fees: What is "Reasonable"? 126 U. PA. L. Rev. 281 (1977); Dobbs, Awarding Attorney Fees Against Adversaries: Introducing the Problem, 1986 DUKE L.J. 435; Leubsdorf, The Contingency Factor in Attorney Fee Awards, 90 YALE L.J. 473 (1981); Rowe, The Legal Theory of Attorney Fee Shifting: A Critical Overview, 1982 Duke L.J. 651, 673-78; Comment, Nonpayment Risk Multipliers: Incentives or Windfalls, 53 U. CHI. L. REv. 1074 (1986). 
ing statutes: to provide for complete enforcement of rights Congress has deemed worthy of special protection. The courts' loss of focus on the underlying purpose of these statutes has led to the current confusion in fee shifting jurisprudence. This Note proposes that courts recognize fee shifting statutes for what they really are: a mechanism to provide an important "public good." 15 Using the example of statutory civil rights actions, this Note will deinonstrate that inany fee shifting statutes serve as a means of providing public goods. Relying on a public goods analysis, this Note shows how a reasonable base fee ${ }^{16}$ that achieves Congress's goals can be calculated. ${ }^{17}$ To that end, the Note will demonstrate that focusing on the opporturnty cost to society of providing civil rights enforcement yields the best calculation of a reasonable fee. ${ }^{18}$ In other words, a reasonable fee should equal the fee that the attorney could have received had she not represented the civil rights plaintiff.

This Note will be linited to statutory fee shifting in civil rights cases and will not specifically address any other type of fee shifting statute. ${ }^{19}$ The limited scope of this Note should not suggest that the following analysis holds relevance only for civil rights cases-this analysis can properly extend to other statutory schemes used to provide public goods. Rather,

15. The definition of a public good will be explored in greater detail infra notes $55-68$ and accompanying text. In general terms, a public good is a good that must be provided through collective action because, once provided, no person can feasibly be excluded from consuming the benefits of the good (e.g., national defense). Characteristically, one person's consumption of a public good does not diminish the supply of the good to all other consumers.

The change from a non-fee-shifting rule to some form of fee shifting does not imply that public goods are involved. A public good is not involved, for example, when fee shifting is used to punish a party for bringing a frivolous suit. Likewise, the adoption of the European approach that encourages the liberal use of fee shifting, see generally Pfennigstorf, The European Experienee with Attorney Fee Shifting, LAw \& CONTEMP. PROBS., Winter 1984, at 37, creates no presumption that a public good is being provided. This Note examines only situations in which Congress has affirmatively decided to use fee shifting as a mechanism to provide greater availability of something that coincidentally satisfies the definition of public good.

16. The "base fee" is simply a fee award made without judicial adjustments for risk of nonpayment or delay in payment. In most instances, the base fee will equal the reasonable fee. See infra notes $37-40$ and accompanying text.

17. See infra notes 126-42 and accompanying text.

18. See infra notes 143-69 and accompanying text.

19. Although this Note is primarily concerned with The Civil Rights Attorney's Fees Awvards Act of 1976, Pub. L. No. 94559, 90 Stat. 2641 (codified at 42 U.S.C. $§ 1988$ (1982)), many cases discussed herein involve other fee shifting statutes in such areas as environmental protection and Freedom of Information Act litigation. The particular statute at issue in each case holds no significance, however, because the Supreme Court has stated that all fee shifting statutes should be identically interpreted. See Hensley v. Eckerhart, 461 U.S. 424, 433 n.7 (1983) ("The standards set forth in this opinion are generally applicable in all cases in which Congress has authorized an award of fee to a 'prevailing party.'") For a comprehensive list of the various fee shifting statutes, see $3 \mathrm{M}$.

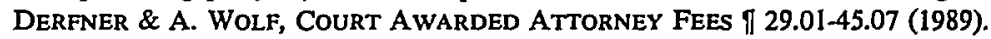


the limited focus provides a convenient setting for developing the important underlying principles.

\section{The Current State of Attorney Fee Shifting Law}

In Alyeska Pipeline Service Co. v. Wilderness Society, ${ }^{20}$ the Supreme Court reaffirned the traditional American rule that parties should bear the costs of their own attorneys ${ }^{21}$ and held that the rule applies in all cases unless Congress has expressly provided otherwise. ${ }^{22}$ The public interest bar, devastated by the Alyeska decision, lobbied Congress to respond quickly to the new requirement for express authorization. ${ }^{23}$ In the civil rights area, Congress responded with The Civil Rights Attorney's Fees Awards Act of 1976 (commouly referred to as section 1988). ${ }^{24}$ Section $1988^{25}$ was enacted with the express intent of negating the effect of the Alyeska decision in cases involving statutory civil rights. ${ }^{26}$

Under section 1988, a party must show that it "prevailed" in the underlying action. ${ }^{27}$ The court then will award attorney's fees unless it determines, in its discretion, that the circumstances of the case do not justify such an award. ${ }^{28}$ If the court deternines that the circumstances

20. 421 U.S. 240 (1975).

21. The rule was first recognized in this country in Arcambel v. Wiseman, 3 U.S. (3 Dall.) 306 (1796). See generally Leubsdorf, Toward a History of the American Rule on Attorney Fee Recovery, LAW \& Contemp. Probs., Winter 1984, at 9.

22. Alyeska, 421 U.S. at 260-62.

23. See Council for Public Interest Law, Balancing the Scales of Justice: FINANCING PUBLIC INTEREST LAW IN AMERICA 314-20 (1976) (recommending congressional response in the form of either a general authorization in all public interest cases or specific authorizations in certain areas of public interest law).

24. Pub. L. No. 94-559, 90 Stat. 2641 (codified at 42 U.S.C. $\S 1988$ (1982))[hereinafter section 1988].

25. Section 1988 provides in relevant part that, "[i]n any action or proceeding to enforce a provision of sections 1981, 1982, 1983, 1985, and 1986 [of title 42], ... the court, in its discretion, may allow the prevailing party, other than the United States, a reasonable attorney's fee as part of the costs." 42 U.S.C. $\$ 1988$.

26. See S. REP. No. 1011, 94th Cong., 2d Sess. 1, reprinted in 1976 U.S. CODE CONG. \& ADMIN. NEWS 5908, 5909 ("[The] purpose of this amendment is to remedy anomalous gaps in our civil rights laws created by the United States Supreme Court's recent decision in Alyeska Pipeline ... .); H.R. REP. No. 1558, 94th Cong., 2d Sess. 2-3; 122 CoNG. REc. 31,471 (1976) (statement of Sen. Mathias); id. at 35,114-15 (statement of Rep. Anderson).

27. The "prevailing party" requirement is generally quite easy to satisfy. No formal relief need be obtained in favor of the prevailing party, S. REP. No. 1011, supra note 26, at 5, reprinted in 1976 U.S. CODE CONG. \& ADMIN. NEWS at 5912, and the party need only secure a result from the action that favorably "affects the behavior of the defendant towards the plaintiff," Hewitt v. Helms, 482 U.S. 755, 761 (1987). See also Miller v. Staats, 706 F.2d 336, 341 (D.C. Cir. 1983) (discussing prevailing party standard); Commissioners Court v. United States, 683 F.2d 435, $441-43$ (D.C. Cir. 1982) (same).

28. Congress apparently intended that a prevailing party "should ordinarily recover an attorney's fee unless special circumstances would render such an award unjnst [sic].” S. REP. No. 1011, supra note 26, at 4 (quoting Newman v. Piggie Park Enters. Inc., 390 U.S. 400, 402 (1968)), re- 
justify such an award of attorney's fees, the real battle begins: the court then must establish a "reasonable" fee.

Althougli the Supreme Court has been less than clear in articulating a general method for calculating a reasonable base fee, the Court appears to call for an approach combining elements of the "subjective factor" method and the "lodestar" method." ${ }^{29}$ The subjective factor method traces its origin back to the Senate report ${ }^{30}$ advocating passage of the bill that became section 1988. In that report, the Senate Judiciary Committee cited Johnson v. Georgia Highway Express, Inc. ${ }^{31}$ as a case that correctly determined a reasonable fee. ${ }^{32}$ Johnson listed twelve nonexclusive factors that should, on a case-by-case basis and weighted according to the discretion of the court, bear on determinations of reasonable fees. ${ }^{33}$ The lodestar nuethod, in comparison, is a judicially created doctrine that originated in the 1973 decision of Lindy Brothers Builders, Inc. v. American Radiator \& Standard Sanitary Corp. ${ }^{34}$ Using the lodestar method, the court determines reasonable fees by multiplying the market value of an hour of the prevailing attorney's time by a reasonable number of

printed in 1976 U.S. CODE CONG. \& ADMIN. NEwS at 5912. Courts have held that an award would be unjust only in the presence of a long litany of special circumstances that disfavor the prevailing party. See, e.g., Buxton v. Patel, 595 F.2d 1182, 1185 (9th Cir. 1979) (judge's denial of award for attorney's fees not an abuse of discretion since case involved principally private benefit, isolated conduct, no bad faith, high chance of success, and adequate compensation available to attorney through the recovery); Green v. Carbaugh, 460 F. Supp. 1193, 1194-95 (E.D. Va. 1978) (fee shifting may not be appropriate where the prevailing party has the ability to pay, and case involves private benefit, isolated conduct, and plaintiff has significant pecuniary motives).

29. See Note, Attorney's Fee Contingeney Enhancements: Toward a Complete Incentive to Litigate Under Federal Fee-Shifting Statutes, 63 WASH. L. REV. 469, 472 (1988) (articulating the hybrid approach of computing fee awards).

30. S. REP. No. 1011, supra note 26, reprinted in 1976 U.S. CODE CoNG. \& ADMIN. NEwS 5908.

31. 488 F.2d 714 (5th Cir. 1974).

32. S. REP. No. 1011, supra note 26, at 6, reprinted in 1976 U.S. CODE CONG. \& ADMIN. News at 5913 .

33. The factors are:

1. Time and labor required.

2. Novelty and difficulty of issues.

3. Skill required to perform legal services.

4. Opportunities foreclosed by representation.

5. Customary fee for similar work in community.

6. Whether fee is fixed or contingent.

7. Time limitations imposed by client or circumstances.

8. Amount of money involved and the results obtained.

9. Experience, reputation, and ability of the attorneys.

10. "Undesirability" of the case.

11. Nature of professional relationship with the client.

12. Awards in similar cases.

488 F.2d at 717-19.

34. 487 F.2d 161 (3d Cir. 1973). 
hours, as determined by the trial judge, to prosecute a similar action. ${ }^{35}$

The Supreme Court, in a series of decisions, ${ }^{36}$ fused the two methods by (1) using the Johnson factors to determine a market hourly rate for the prevailing attorney, (2) multiplying that rate by a reasonable number of hours for prosecution of the action to establish the lodestar, and (3) subsequently adjusting the lodestar up or down if a Johnson factor was not adequately reffected in the inarket hourly rate. ${ }^{37}$ Generally, courts presuine the lodestar to be the appropriate and reasonable base fee, ${ }^{38}$ and adjustinents are made only in rare or exceptional circuinstances. ${ }^{39}$ Consequently, the determination of the prevailing attorney's market hourly rate is of crucial importance in the fee calculation.

Because this Note seeks to redefine the calculus for a prevailing attorney's market hourly rate, the mechanics used to arrive at such a rate in the current hybrid system must first be explained. Defining the relevant legal market presents the first challenge to arriving at an appropriate market lourly rate. As the Court stated in Blum v. Stenson, the type of legal service provided and the community in which that service is provided determines the proper market. ${ }^{40}$ Currently, district courts must evaluate and balance the Johnson factors that relate to the coinmunity or type of service involved. For example, attorney representation in a simple freedom of speech clain in Jackson, Mississippi delineates a legal inarket coinpletely different from that defined by attorney representation in a complex employment discrimination case in Washington, D.C.41

Having isolated the proper legal market, the court then must find a "prevailing" rate for a lawyer of "reasonably comparable skill, experience and reputation" in that niarket. ${ }^{42}$ The prevailing attorney's customary hourly billing rate is not determinative; ${ }^{43}$ instead, the court evaluates the Johnson factors that bear on the attorney's skill, experience, and reputation. Although this approach is convoluted, its simple purpose is to direct lower courts to decide on a fair price (the market rate) for a good

35. See Third Circuit Task Force, Court Awarded Attorney Fees, 108 F.R.D. 237, 242-46 (1985) (explanation of lodestar method and discussion of its acceptance).

36. See Blanchard v. Bergeron, 109 S. Ct. 939, 944-45 (1989); Delaware Valley II, 483 U.S. at 717-724; Delaware Valley 1, 478 U.S. at 561-68; Blum v. Stenson, 465 U.S. 886, 896-97 (1984); Hensley v. Eckerhart, 461 U.S. 424, 434 (1983).

37. See Blanchard, 109 S. Ct. at 945; Leading Cases: Attorneys' Fees, 101 Harv. L. Rev. 290, 291 (1987); Note, supra note 29, at 472-73.

38. See Blum, 465 U.S. at 897.

39. See Delaware Valley II, 483 U.S. at 715-17 (enumerating circumstances).

40. Blum, 465 U.S. at $895-96$ n.11.

41. Obviously, billing rates vary drastically between large, urban settings and more rural settings. Also, billing rates tend to vary with the complexity of the task.

42. Blum, 465 U.S. at $895-96$ n.11.

43. Id. (public interest attorney may be credited with prevailing market billing rate). 
(the attorney of a particular skill) in a unique market (the type of legal work and community).

The Blum Court expanded the scope of the hybrid approach when it held that the prevailing market rate should be used to calculate an award even when the party is represented by a nonprofit legal service organization. ${ }^{44}$ The Court rejected the argument that using the market rate would bestow a "windfall on a nonprofit organization."45 In applying the prevailing market rate to nonprofit legal services, the Court noted Congress's implicit approval of the inarket rate approach and Congress's failure to distinguish among different types of attorneys. ${ }^{46}$

Presently, reasonable fee jurisprudence is a combination of the Johnson factors and the lodestar inethod, and it warrants most of the criticism and controversy showered upon it. The current law has been criticized for being too subjective (thus producing inconsistent results), ${ }^{47}$ causing an enormous increase in litigation, ${ }^{48}$ and creating a disincentive for early

44. Id. at 895 .

45. The Senate and House reports, as well as the debates on the floors of the Senate and House, all indicate that Congress was concerned that section 1988 would become a "bonanza to the legal profession." 122 CoNG. Rec. 31,473 (1976) (statement of Sen. Allen). Congress therefore emphasized that "reasonable" attorney's fees should not be construed to provide windfalls for attorneys. See S. REP. No. 1011, supra note 26, at 6, reprinted in 1976 U.S. CODE CONG. \& ADMIN. NEWS at 5913; H.R. REP. No. 1558, supra note 26, at 9.

46. Blum, 465 U.S. at 893-95.

The United States Court of Appeals for the District of Columbia Circuit, sitting en banc in Save Our Cumberland Mountains, Inc. v. Hodel, 857 F.2d 1516 (D.C. Cir. 1988), recently reexamined the liberal use of attorney billing histories to establish market rates. In Cumberland Mountains, the D.C. Circuit vacated an earlier panel decision holding that when a private, profit-oriented firm represents a party at a discount hourly rate for similar work, the reduced rate is presumptively the appropriate rate. 826 F.2d 43 (D.C. Cir. 1987). Judge Bork, writing for the panel, reasoned that because the attorney for Save Our Cumberland Mountains agreed to represent the organization for a reduced rate, the reduced rate must have been adequate to attract competent counsel to similar cases, thus satisfying congressional intent. Id. at 49. Judge Sentelle, writing for a majority of the en banc court, reversed the panel and, relying heavily on Blum, held that the prevailing market rate approach applied not only to traditional profit-oriented firms and non-profit organizations, but also to reduced-rate private firms. Cumberland Mountains, 857 F.2d at 1524. In dissent, Judge Starr attempted to flesh out Judge Bork's unconvincing reasoning in the panel opinion by arguing that a customary (reduced) billing rate is presumptively the produet of market forces (the implication being that the reduced rate must then be adequate to attraet competent counsel in general). Id. at 1530 (Starr, J., dissenting).

47. See National Ass'N of ATtorneys General, supra note 7, at 27-30 (finding laek of meaningful judicial standards and recommending congressionally imposed fee cap of $\$ 75$ per hour); Breger, Compensation Formulas for Court Awarded Attorney Fees, LAW \& ConTEMP. ProBs., Winter 1984, at 249, 266 (discussing Supreme Court's previously adopted awkward position that a reasonable rate depends on the prevailing market rate in a community, while at the same time recognizing that in the traditional sense there is no prevailing market rate for the service of lawyers in a community).

48. See Court Awarded Attorney Fees, supra note 35, at 246 (present fee-setting process magnifies the proceedings and "increases the workload of an already overtaxed judicial system"); see also 
settlement of cases. ${ }^{49}$ But the most relevant criticism for purposes of this Note is that the prevailing market approach tends to value highly certain types of attorneys, such as antitrust attorneys seeking fees under the Clayton Act, and undervalue other types of attorneys, such as civil rights attorneys seeking awards under section $1988 . .^{50}$ As will be discussed below, ${ }^{51}$ the courts' failure or unwillingness to approach the definition of a reasonable fee from a public goods perspective inevitably produces such an anomolous valuation of attorney time.

\section{The General Theory of Public Goods}

The proposition that the enforcement of civil rights is a public good requires a review of the general economic theory of public goods and local public goods. ${ }^{52}$ The body of writing on public goods, although extensive and well developed, is far from consistent. ${ }^{53}$ Nevertheless, this Note will present basic principles upon which most economists agree.

\section{A. Definition of Public Goods}

A practical approach to public goods developed through legislation long before the appearance of a generalized theory in economic literature. ${ }^{54}$ In 1572, the British Parliament responded to the "liorryble Murders Theft and other greate Outrag" caused by the increasing number of vagabonds and beggars by enacting the first law designed to

Cumberland Mountains, 857 F.2d at 1525 (noting that the litigation over attorneys fees started in 1985 and lasted over three years).

49. See Court Awarded Attorney Fees, supra note 35, at 248 (emphasis on hours worked may leave little incentive to settle early).

50. See id. at $248-49$ (Lindy process may disadvantage public interest bar).

51. See infra notes 73-109 and accompanying text (discussing problem of hidden public demand for civil rights enforcement).

52. See infra notes 98-100 (discussing local public goods).

53. See, e.g., Buchanan, Public Goods in Theory and Practice: A Note on the Minasian-Samuelson Discussion, 10 J.L. \& EcoN. 193 (1967) (analyzing the advantages and disadvantages of privately supplied and publicly supplied television signals); Minasian, Public Goods in Theory and Practice Revisited, 10 J.L. \& ECON. 205 (1967) (same); Samuelson, Pitfalls in the Analysis of Public Goods, 10 J.L. \& ECON. 199 (1967) (same).

54. In early England, manorial communities required a certain amount of common land on which animals could pasture. Without such common pastures, the agricultural production of the manor would suffer. See N. Hone, The MaNor and MaNorial Records 110-11 (1906). Apparently, private individuals could not provide the land. In response, the "lord's waste" was open to all tenants' animals for pasture. Id. The fact that in some townships only animals that had wintered in the manor were allowed to graze on the commons, see P. ViNoGRadofF, VillaiNaGe IN ENGLAND 262 (1892), demonstrates that the commons served the economic interest of the manor rather than any humane interest in the cattle's welfare. The commons provides a historical example of a good that theoretically could be provided privately, but realistically could be provided more efficiently by collective action. See A. AtKinson \& J. Stiglitz, Lectures on Public Economics 483-84 (1980). 
give rehef to the poor through compulsory taxation and redistribution..$^{55}$ The Parliament made it clear that the relief was not given for purely altruistic reasons, but primarily for the purpose of mitigating the "great annoye of the Comon Weale." 56 Seventy years later, the people of Massachusetts determined that the minister's house in each town should be subsidized by a public charge on all inhabitants of the town. ${ }^{57}$ The people presumably imposed this tax not for the benefit of the ministers alone, but for the happiness of the colony as a whole. ${ }^{58}$

These examples, along with the commonly used example of national defense, illustrate what central governments for centuries have recognized: that many types of valuable and necessary goods would remain underprovided by the free market. ${ }^{59}$ Nevertheless a general definition of the type of good that requires public provision remained elusive until Sidgwick's and Pigou's works in the late nineteenth and early twentieth centuries. ${ }^{60}$ Sidgwick and Pigou made crucial contributions to the work of Adam Smith"1 by introducing and analyzing the concept of the "free

55. An Acte for the Punishement of Vacabondes, and for Releif of the Poore \& Impotent, 1572, 14 Eliz., ch. 5, §§ 1, 16. See generally 3 E. LIPSON, THE EConomic History of ENGLAND 416-18 (4th ed. 1947) (discussing the development of English poor laws).

56. 14 Eliz., ch. 5, at § 1. See generally G.B. Shaw, Major Barbara 142 (1960) ("Only fools fear crime: we all fear poverty.").

57. The BooK of the General LaUues and Libertyes ConCerning the InHABitants OF THE MASSACHUSETS $\S 16$ (1648).

For other early examples of this type of collective action, see MASs. CONST. pt. 1, art. III (1853) (empowering legislature to compel provision of public worship for the "happiness" of all people); An Act to Supply Some Defects in the Laws for Repairing and Rebuilding County Bridges, for Repairing, Enlarging, Erecting, and Providing Houses of Correction, and for Passing Rogues and Vagabonds, 1741, 14 Geo. 2, ch. 33; An Act for Erecting of Pounds in Each Township of this Province, ch. 301, § 5, $1729 \mathrm{~Pa}$. Acts 221, 224 (public provision of animal pounds); Act of Mar. 5, $1624, \S 15,1623-1624$ Va. Laws \& Orders 421, 425 (public provision of grainery).

58. See MAss. CONST. pt. 1, art. III (1853).

59. See Pearce, Justifiable Government Intervention in Preserving the Quality of Life, in PUBL1C ECONOMICS AND THE QUALITY OF LIFE 125, 125-26 (L. Wingo \& A. Evans eds. 1977).

60. See A. Pigou, The Economics of Welfare 183-88 (4th ed. 1932); A. Pigou, A Study in Public Finance 118-20 (1929); H. Sidgwick, The Principles of Political Economy 406 (3d ed. 1901) (fathering the now-famous lighthouse example).

61. Adam Smith, certainly not one of history's leading welfare economists, acknowledged the existence of certain market failures. Smith concluded that three basic types of goods require public provision: (1) national defense, (2) the administration of justice, and (3) public works and institutions. A. SMith, AN Inquiry into the Nature and Causes of THE Wealth of Nations 653-766 (E. Cannan ed. 1937); see also Buchanan, Public Goods and Natural Liberty, in THE MARKET AND THE STATE: ESSAYS IN HoNour OF ADAM SMITH 271 (T. Wilson \& A. Skinner eds. 1976) (discussing Smith's analysis of collective provision of goods); Musgrave, Adam Smith on Pub. lic Finance and Distribution, in The MARket and the State: Essays in Honour of Adam SMrTH, supra, at 296 (Smith's views a "fore-runner to the modern theory of social goods"). Smith's insightful analysis did little, however, to provide a generalized definition of a public good. 
rider" as an essential element of the definition of public goods. ${ }^{62}$ According to Sidgwick and Pigou, a good must be publicly provided when it can be consumed by persons from whom payment cannot be exacted. ${ }^{63}$ Otherwise, free riders can consume goods at little or no cost to themselves and destroy the incentives for private provision.

Paul Samuelson helped give structure to the previously amorphous concept of public goods in his series of articles on the theory of public expenditure.64 Samuelson posited that a public good exhibits two essential characteristics: (1) no member of a community im which the good is produced can be prevented from consuming or enjoying the good (the free-rider problem), and (2) each member's consumption of the good, once provided, does not subtract from the supply available for other members' consumption. ${ }^{65}$ The former characteristic is often called "nonexcludabihty" while the latter condition is referred to as jointness of supply, or "nonrivalrousness." 66

Although Samuelson's definition of a pure public good remains widely accepted, it fails to address the vast majority of goods that share characteristics of both purely private and purely public goods. ${ }^{67}$ For example, a public bridge can be established as nonexcludable, but at some point it becomes congested with patrons; consequently it exhibits a certain amount of rivalrousness. Although such a good does not fit precisely into Samuelson's analysis, recent developments in the area indicate

62. A "free-rider" is one who consumes valuable goods at little or no expense to himself. Nontaxpayers, for example, are free-riders with respect to the protection they receive from police or fire departments.

63. See A. Pigou, supra note 60, at 183-84; H. Sidgwick, supra note 60, at 406 (cost of lighthouses cannot be practically apportioned among those enjoying beneficial effects).

64. Samuelson, Aspects of Public Expenditure Theories, 40 REv. EcoN. \& STATisTics 332 (1958) [hereinafter Samuelson, Aspects]; Samuelson, Diagrammatic Explanation of a Theory of Public Expenditure, 37 REv. EcoN. \& STATISTICs 350 (1955) [hereinafter Samuelson, Diagrammatic Explanation]; Samuelson, The Pure Theory of Public Expenditure, 36 REv. EcoN. \& STATISTICs 387 (1954) [hereinafter Samuelson, Pure Theory].

65. See Samuelson, Diagrammatic Explanation, supra note 64, at 350; Samuelson, Pure Theory, supra note 64 , at 387 . Samuelson's definition, although occasionally criticized for its failure to consider mixed goods (i.e., goods that are only partially nonexcludable or jointly supplied, such as a public museum), see R. BENJAMIN, The LIMITS of Politics 10 (1980), has been almost universally accepted as the proper definition of a pure public good. See, e.g., id. at 9-11; J. HENDERSON \& R. Quandt, Microeconomic Theory: A Mathematical Approach 298 (3d ed. 1980); P. JoHANSSON, THE ECONOMIC TheORY AND MEASUREMENT OF ENVIRONMENTAL BeNefits 72 (1987); E. Morgan \& A. Morgan, The Economics of Public Policy 70-71 (1972).

66. See D. Starrett, Foundations of Public Economics $42-44$ (1988).

67. See R. BENJAMIN, supra note 65 , at 10 (" $[\mathrm{I}] \mathrm{n}$ between the analytical poles of 'pure' public and 'pure' private goods are ... goods that are called quasi-public or quasi-private or are considered not exclusively private and thus collective in nature."). 
that Samuelson's theory must be modified only slightly to accommodate such mixed goods. ${ }^{68}$

\section{B. The Provision of Public Goods}

Samuelson's theory of public goods departs from the Pigovian tradition of focusing on the proper level of taxation to supply the needed level of goods. Instead, Samuelson's approach to public economics is rooted in public expenditures ${ }^{69}$ and the use of individual consumers' utility functions, ${ }^{70}$ aggregated across society, to determine the efficient level at which public goods should be provided. Samuelson and his followers have achieved only limited success in deriving individual utility functions for public goods. ${ }^{71}$ Part of the problem lies with continually changing consumer preferences over time. ${ }^{72}$

The larger problem that Samuelson and countless others have faced stems from the unavoidable fact that, because public goods are nonexcludable, consumers of such goods have no incentive to accurately reflect their demand for the goods. ${ }^{73}$ A natural tendency exists for a consumer to mask his true desire to purchase public goods if the cost of such projects is already borne in large part by others. Users of a public bridge, for example, although deriving a certain amount of utility from each use, will in fact misrepresent their marginal utility 74 if allowed to use the bridge without paying. Strategic (and predictable) behavior on the part of consumers of public goods will lead to significant underprovision

68. See R. CORnes \& T. SANDler, The Theory of Externalities, Public Goods, AND CLUB Goods 124-28 (1986) (providing analysis of mixed goods); J. DAvis \& J. HULETT, AN ANALySis of Market Failure: Externalities, Public Goods, AND MiXed Goods $46-47$ (1977) (same); D. STARRETT, supra note 69, at 44-47 (same).

69. See Samuelson, Aspects, supra note 64, at 332.

70. Utility is simply psychological satisfaction. See, e.g.; R. LIPSEY, P. STEINER \& D. PURVIS, EcoNOMics 129 (8th ed. 1987). A utility function is a linear function that traces the level of enjoyment a consumer derives from consuming certain quantities of a good.

Throughout this Note, all utility functions will involve two variables: the quantity of public goods and the quantity of private goods. Also, throughout this Note, the utility functions are assumed to be continuous and to have strictly positive partial derivatives, which implies that more of the good under investigation is always better than less.

71. See infra notes 79-82 and accompanying text.

72. See, e.g., E. MANSField, Microeconomics: Theory \& Applications 73 (4th ed. 1982) (consumer preferences can vary with increasing age and education).

73. See J. Due \& A. Friedlaender, Government Finance: Economics of the Public SECTOR 51-52 (5th ed. 1973) (once people realize public goods are available, there is no incentive to reveal their true preferences).

74. Marginal utility refers to the additional incremental utility enjoyed by the consumer from the consumption of one more unit of a good (in this case, trips across the bridge). Although a consumer will value twenty trips across the bridge more than nineteen, it is likely that her enjoyment from the additional, i.e., marginal, trip will wane if offered twenty-one trips and then twenty-two. 
because the consumers' marginal utility derived from additional units of public goods will remain understated. ${ }^{75}$

Samuelson resolved this dilemma by assuming the existence of something akin to an omniscient central planner privy to each individual's preference for private and public goods. ${ }^{76}$ With this hidden information at her disposal, the planner can sum the individual marginal utilities across society with respect to both public and private goods. Dividing individuals' summed marginal utilities yields a "marginal rate of substitution" (MRS) between the public and private good. The MRS is the rate at whicli society is willing to substitute one good for the otler while maintaining a constant level of utility. For example, society may be indifferent between (i.e., derive the same utility from) an article of clothing wortli fifty dollars and twenty trips across a new public bridge.

The central planner subsequently calculates the "rate of product transformation" (RPT), or the rate at which one good must be sacrificed, due to society's physical constraints of production, to produce one more of the otlier good, holding all factors of production constant. The point at which the society's MRS equals its RPT reveals to the central planner the proper mix of public and private goods given a constant constraint on the factors of production. ${ }^{77}$ Such a mix achieves the goal of Pareto efficiency. ${ }^{78}$ With this allocation between public and private goods: the

75. See E. Clarke, Demand Revelation and the Provision of Public Goods 45-46 (1980) (noting that if people are taxed in proportion to the benefit they claim for a public good, then it is in their interest to claim almost no benefit); Lee, Discrimination and Efficiency in the Pricing of Public Goods, 20 J.L. \& EcoN. 403, 403 (1977) ("Since each consumer can benefit from the public good that someone else pays for, the prevailing sentiment is to pretend no desire for the good and hope for a free ride."); van de Kragt, Orbell \& Dawes, The Minimal Contributing Set as a Solution to Public Goods Problems, 77 AM. PoL. SC1. REV. 112, 112 (1983) (rational and selfish individuals will recognize opportunity to "free ride" on contributions from others, knowing they can share in good once provided, and therefore will withhold or curtail contributions).

76. Samuelson never expressly adopts the model of an omniscient central planner, but it is implicit in his discussion. See J. DUE \& A. FrIedlaENDER, supra note 73, at 52-54 (assumption that there is an omniscient planner who knows individual preferences for public and private goods).

77. This equilibrium condition between society's MRS and RPT is the second of Samuelson's three optimal conditions. See Samuelson, Pure Theory, supra note 64, at 387, 388. This condition is stated as: Sum(individual MRS) $=$ RPT. The first condition deals only with private goods. Id. The third is not relevant at this point. For other similar mathematical derivations, see J. DAvis \& J. HULETT, supra note 68, at 35 (equations 3.10 and 3.11); J. HENDERSON \& R. QUANDT, supra note 65 , at 299-300 (equation 11-24).

78. A Pareto-efficient allocation is the allocation of private goods and public goods that leads to the highest attainable level of utility for a society, given current production restraints. Pareto efficiency requires that no individual's utility can be increased without decreasing another individual's utility. The definition of Pareto efficiency is distinguishable from a concept that is often confused with Pareto efficiency: wealth maximization. Wealth maximization focuses solely on the sum of individuals' wealth, while Pareto efficiency focuses on individual utility. See Dworkin, Is Wealth a Value?, 9 J. LEgal STud. 191, 192-94 (1980). Judge Posner makes the following clarification: [T] he wealth of society is the aggregate satisfaction of those preferences . . that are backed up by 
marginal utility derived from adding the last unit of the public good equals the marginal cost of producing the good: the system is in equilibrium. Society's welfare therefore cannot be increased by any further shifting of resources.

As noted earlier, Samuelson's approach only partially succeeds in developing a workable model. Surely, by shifting responsibility for the provision of public goods to central planners, the problem of exacting payments from consumers is resolved. ${ }^{79}$ However, one could argue that the problem is merely avoided rather thian resolved: Samuelson's central planner still cannot exact true preferences from free-riding consumers. Thus, the planner cannot derive individual or societal utility functions, and the solution becomes only a theoretical one. ${ }^{80}$ Samuelson himself admitted that a final solution would require a departure from pure economics into the realm of sociology and welfare politics. ${ }^{81}$

In response to this gap in Samuelson's theory, much of the recent public goods literature lias focused on theoretical and empirical methods to elicit true consumer preferences for public goods. ${ }^{82}$ The continuing inability to cure tlie hidden demand problem will resurface later in this Note, when the proper metliod of enforcing civil rights is discussed.

\section{Is the Enforcement of Civil Rights A Public Good?}

The end of the institution, maintenance, and administration of government, is to secure the existence of the body politic, to protect it, and to furnish the individuals who compose it with the power of enjoying in safety and tranquility their natural rights . . . ${ }^{83}$

money, that is, that are registered in a market." $R$. POSNER, THE ECONOMICs of JusTice 61 (1983) (emphasis added). Thus, while Vilfredo Pareto would take into account all individuals' utility functions, a wealth maximizer considers only those utility functions that, with the backing of money, are reflected in the marketplace. Id. at 60-61.

79. This assumes that the planner has the power to tax.

80. J. DUE \& A. FriedLAENDER, supra note 73, at 53-54 (people will not state true preference as long as tax payments depend on their preferences; therefore any solution analogous to the market is unsatisfactory); see also E. MORGAN \& A. MORGAN, supra note 65 , at 73-74 (neither a market decision nor a political decision is likely to produce ideal result, since market decision leads to underprovision because of difficulty of collecting payment, and joint nature of public goods causes a political solution to lead to underprovision as well).

81. Samuelson, Pure Theory, supra note 64, at 389.

82. See, e.g., K. ARrow, Social Choice and Individual Values 9-19 (2d ed. 1963); A. Atkinson \& J. Stiglitz, Lectures on Public Economics 513-15 (1980); E. Clarke, supra note 75, at 71-102 (discussing the incentive tax method of demand revelation); $R$. CoRNES \& $T$. SANDLER, supra note 68, at 102-12; J. HEAD, PUBLIC GoodS AND PUBLIC Welfare 86-91 (1974); Brookshire \& Coursey, Measuring the Value of a Public Good: An Empirical Comparison of Elicitation Procedures, 77 AM. Econ. Rev. 554, 554-57 (1987); Buchanan, From Private Preference to Public Philosophy: The Development of Public Choice, in THE Economics of Politics 8-10 (1978).

83. Mass. Const. preamble (emphasis added). 
To determine whether the enforcement of civil rights can be characterized, and thus analyzed, as a public good, this part will address, in relation to civil rights enforcement, basic characteristics of a public good: nonexcludability and nonrivalrousness. This part also will explore the problem of privately supplied public goods in this context.

Before proceeding, however, a definitional clarification should be made. Civil rights cases, for the most part, involve attorneys who agree to represent clients for reduced fees, or no fee at all. In such cases, the attorney essentially enters into a partnership with the client by assuining the financial risk of success and by deriving a significant, if not complete, portion of his remuneration from the fee award. The attorney's interests in prevailing in the case essentially match those of the client. Consequently, the client and the civil rights attorney are both consumers of civil rights enforcement as a public good. Thus, references to "consuiners" of such a public good include necessarily attorneys and chents.

\section{A. Nonexcludability}

Significantly, Adam Smith in his landmark Wealth of Nations included within his three duties of the sovereign the duty of providing "justice."84 Although Smith refrained from theoretical discussions of why his three types of public goods should be publicly provided, his writing on the supply of justice reflects an awareness of something smilar to the modern concept of nonexcludability:

It is only under the shelter of the civil magistrate that the owner of that valuable property, which is acquired by the labour of many years, or perhaps of many successive generations, can sleep a single night in security. He is at all times surrounded by unknown enemies, whom, though he never provoked, he can never appease, and from whose injustice he can be protected only by the powerful arm of the civil magistrate continually held up to chastise it. ${ }^{85}$

Smith recognized that justice confers upon all owners of valuable property the benefit of physical security and peace of mind. Even those property owners who, in the absence of publicly provided justice, would not have suffered an invasion of their possessions receive a protective benefit. Certainly no feasible method of exacting payment to reflect the quantum of protective benefit received can be devised. Consequently, Smith probably would conclude today that the provision of justice is not excludable. ${ }^{86}$

84. A. SMITH, supra note 61 , at $669-81$ (second duty of sovereign is "protecting as far as possible, every member of society from the injustice or oppression of every other member of it").

85. A. SMITH, supra note 61 , at 670 .

86. See Buchanan, supra note 61 , at 275 (noting that the provision of justice, as envisioned by Smith, "enter[s] the utility functions of individuals, . . . and . . . must be (or should be) made 
Although one might construe Smith's eighteenth-century concept of justice as protecting the "haves" from the "have-nots," his analysis can easily extend to the enforcement of a citizen's civil rights. It is a fundamental tenet of civil rights doctrine that civil rights enforceinent as to one person or class of persons inures to the benefit of all citizens. ${ }^{87}$ This societal benefit may take one of three forms. First, when the civil rights of one person are protected, other members of the society receive a psychic benefit of security in knowing that their civil rights also will be protected, if necessary. ${ }^{88}$ Second, there is a direct, physical benefit which inures to the class of people protected by civil rights enforceinent. For exainple, when a city ordinance infringes its employees' rights of free speech, an injunction against the city benefits not only those einployees who bring suit, but also all other city einployees and all other government einployees similarly situated. ${ }^{89}$ Third, civil rights enforceinent enhances society's quality of life. This is the positive spillover benefit received froin another individual's exercise of her civil rights. For example, all society derives economic benefit from the einployinent of highly

generally available to all members of the community") (emphasis added). Buchanan concludes that Smith's provision of justice, or laws, as Buchanan calls it, "embodies polar or extreme publicness" and "is wholly consistent with modern public goods analysis." Id. at 276-77.

87. See 122 CoNG. REC. 33,313 (1976) (statement of Sen. Tunney) (When a citizen seeks to enforce his civil rights and the right "he seeks to assert and vindicate goes unvindicated ... the entire Nation, not just the individual citizen suffers.").

88. A finding of this type of broad societal benefit follows from the many cases in which courts were asked to determine if a successful civil rights action created a private or public benefit. See, e.g. Wheatley v. Ford, 679 F.2d 1037, 1040 (2d Cir. 1982) ("Yet, actions [for unlawful arrest and excessive use of forcel which deter police overreaching benefit society as a whole."); Fox v. Parker, 626 F.2d 351, 353 (4th Cir. 1980) ("Certainly, the vindication of an individual's civil rights inures to the benefit of all citizens."); Hoitt v. Vitek, 495 F.2d 219, 220 (1st Cir. 1974) ("the public, as well as all present and future prisoners, benefits when the constitutionality of the treatment of prisoners is assured").

Congress, when it enacted section 1988, surely was aware of the public's security benefit derived from enforcing civil rights laws. See, e.g., 122 CoNG. REc. 35,127 (1976) ("[T] he person who brings such a case functions as a 'private attorney general' and acts not only for himself but also to enforce our laws.") (statement of Rep. Holtzman). While debating the passage of what eventually became sections 1983, 1985, and 1986 of title 42 , Congressman Lowe forcefully articulated the security benefit argument:

[I]f the rights of citizenship may be denied without redress, if the Constitution may not be enforced, ... then, indeed, is our civil Government a failure, and instead of enjoying liberty regulated by law, its subjects may live only by the sufferance of lawless and exasperated conspirators.

CoNG. Globe pt. 4, at 374 (1871) (statement of Rep. Lowe) (debating Act of Apr. 20, 1871, ch. 22, 17 Stat. 13 (codified as amended at 42 U.S.C. $\$ \$ 1983,1985,1986(1982)$ )).

89. Cf. Taylor v. Jones, 653 F.2d 1193, 1202-04 (8th Cir. 1981) (requiring employer to hire at least one black person for every two white persons employed). See generally Newman v. Piggie Park Enters., 390 U.S. 400, 402 (1968) ("If he obtains an injunction, he does so not for himself alone but also as a 'private attorney general,' vindicating a policy that Congress considered of the highest priority."), cited in S. REP. No. 1011, supra note 26, at 3, reprinted in 1976 U.S. CODE CONG. \& ADMIN. NEws at 5910. 
qualified minorities or the societal benefit derived from affirmative action in college admissions, ${ }^{90}$ or the cultural benefit derived from the expansion of the marketplace of free speech. ${ }^{91}$

A shared trait binding all three types of benefits is the lack of a feasible method for exacting payments from those individuals who enjoy the benefits. When individuals freely consume without expense, the freerider effect prompts such consumers to understate their true benefit, thus leading to an underprovision of the good.92 Thus, civil rights enforcement exhibits the characteristic of nonexcludability, and appears, thus far, to be a classic example of a pure public good.

\section{B. Nonrivalrousness}

A public good exhibits not only nonexcludability, but also nonrivalrousness, or nondimmishing joint supply. ${ }^{93}$ Therefore, civil rights enforcement constitutes a pubhic good only if one citizen's consumption of that enforcement does not reduce the supply of enforcement available to all other citizens. Significantly, excess demand for a public good does not necessarily imply that the public good is not jointly supplied. Joint supply means only that once a public good is supplied, it can be enjoyed by all; 94 that is to say the opportunity cost to the marginal user of the good is zero. 95

The demand for civil rights enforcement may exceed its supply, ${ }^{96}$

90. See Regents of the Univ. of Cal. v. Bakke, 438 U.S. 265, 311-14 (1978) (Powell, J.) (discussing benefits to universities from increased diversity).

91. See Texas v. Johnson, 109 S. Ct. 2533, 2547 (1989) ("The way to preserve the flag's special role is not to punish those who feel differently about these matters. It is to persuade them that they are wrong."); Abrams v. United States, 250 U.S. 616, 630 (1919) (Holmes, J., dissenting) ("the ultimate good desired is better reached by free trade in ideas"); H. BLACK, A ConsTrTUTIONAL FAITH 49 (1968) ("Free speech plays its most important role in the political discussions and arguments which are the lifeblood of any representative democracy.").

92. See supra notes 62-63 and accompanying text.

93. To illustrate the concept of "joint supply," suppose the government of Washington, D.C. enacts various regulations that restrict certain types of expression by district employees. Suppose also the number of district employees wanting to challenge these restrictions far surpasses both the number of attorneys willing to handle such matters and the resourees of district courts. If, however, several plaintiffs retain lawyers and successfully obtain injunctions against the district government, all district employees will benefit. Thus, demand initially exceeds supply of civil rights enforcement, but once supplied, the enforced civil right necessarily is supplied to all other employees.

94. E. MORGAN \& A. MORGAN, supra note 65 , at 71.

95. See D. STARRETT, supra note 66 , at $43-44$.

Opportunity cost refers to the value of the next best alternative use of one's resources. For example, the opportunity cost of one hour of leisure equals the value of one hour of work, or the opportunity cost of buying a car is the value that a consumer places on the other things she could do with the car's purchase price. If the opportunity cost of a good is zero, then the consumer can consume the good for "free"; i.e., she has to give nothing of value in order to consume the good.

96. See supra note 93. 
but once a particular right is enforced, one person's enjoyment of that enforced right does not diminish any other person's ability to enjoy that right. An injunction, for example, is not a wasting asset and is not subject to congestion like the public bridge previously discussed. Similarly, the deterrent effect of damages does not progressively diminish each time a person enjoys that deterrent effect. Thus, once a civil right is enforced for one person, the enforced right necessarily can be enjoyed by all people.

\section{Private Provision of Civil Rights}

Although the provision of civil rights satisfies the traditional definition of public goods, one could argue that Congress has not treated such provision as a public good, since section 1988 (and all other fee-shifting statutes) requires private parties, as well as public parties, to pay fee awards.

If the government subsidized all fee awards paid by private defendants under section 1988, then public goods analysis would easily apply. But if just private parties are involved, fee shifting alters only the relationship between the parties and is not amenable to traditional public goods analysis. For example, when a private employer has discriminated in hiring practices, the employer, not the government, pays the plaintiff's attorney's fees. ${ }^{97}$

This argument, however, fails to consider that entities smaller than the central government can provide public goods. An entity provides a local public good when the benefits of the good affect a relatively small jurisdiction, such as a municipality. ${ }^{98}$ Frequently, the jurisdiction for exacting payment for the public good is even smaller than the jurisdiction that receives benefits from the good. ${ }^{99}$ For example, suppose Employer is a regional power company that discriminates in its hiring practices. As discussed above, the benefits from a ruling against Employer accrne to all citizens; but the Employer can exact payments through higher prices only from its regional customers. Thus, the benefits provided by Employer "spill over" beyond its economic jurisdiction. ${ }^{100}$

97. See, e.g., Allen v. Terminal Transp. Co., 486 F. Supp. 1195, 1201-02 (N.D. Ga. 1980), aff'd summ. sub nom. United States v. Terminal Transp. Co., 653 F.2d 1016 (5th Cir. 1881), cert. denied, 455 U.S. 989 (1982).

98. See R. CORNes \& T. SANDLER, supra note 68 , at 24 (describing local public goods as including city parks, roadways, museums, and tennis courts).

99. Id.

100. See id. ("[W]hen a public good confers benefits outside the political jurisdiction that provides it and no compensation is paid by these outside recipients, spillovers of benefits exist.") 
Such a complication, however, is not fatal to this Note's analysis. Under local public goods analysis, the inethod of determining an equilibrium level of public goods by each local entity differs from the traditional Samuelsonian approach. ${ }^{101}$ Indeed, the equilibrium obtained under the local approach is not the Pareto-efficient provision of goods, since consumers within each entity's jurisdiction take advantage of free-rider opportunities by consuming benefits provided across economic jurisdictions. Thus, the equilibrium reached locally will result in the underprovision of the good because of hidden demand. ${ }^{102}$ Although the analysis of local public goods differs from the analysis of public goods provided by the national government, the problem is the saine-the freerider problein, which is caused by a failure of the market to reveal true consumer preferences. ${ }^{103}$ Since this Note proposes a solution that focuses on correcting the problem of demand revelation, the analysis used in this Note apphes to public-goods provided not only by national entities, but also by local, state and regional entities. ${ }^{104}$

\section{Civil Rights Enforcement as a Public Good}

Civil rights enforcement by local and national entities satisfies the two-part definition of public goods accepted in most public goods literature. Consequently, one would expect to find evidence that civil rights are under-enforced if provided by the private market. Courts, ${ }^{105}$ Congress, ${ }^{106}$ and scholars ${ }^{107}$ all agree that if left to private enforcement, civil

101. See id. at 18-22 (entities react to other entities' provision until an equilibrium is reached).

102. See id. at 24.

103. See id.

104. For simplicity, this Note will frequently refer to the "government" as the supplier of a public good. The use of that term is intended to refer to both the national and state governments as well as local, private suppliers of public goods.

105. See, e.g., Newman v. Piggie Park Enters., 390 U.S. 400, 402 (1968) ("[I]f successful plaintiffs were routinely forced to bear their own attorneys' fees, few aggrieved parties would be in a position to advance the public interest by invoking the injunctive powers of the federal courts."); Wheatley v. Ford, 679 F.2d 1037, 1040 (2d Cir. 1982) (court should consider whether similarly situated plaintiffs would be deterred from bringing civil rights' action absent the likelihood of an award for attorney's fees in action for unlawful arrest and excessive use of force).

106. See, e.g., 122 CoNG. Rec. 31,471 (1976) (statement of Sen. Scott) ("Congress must insure that [citizens] have the means to go to court and to be effective once they get there"); $i d$. at 33,313 (statement of Sen. Tunney) ("When Congress calls upon citizens ... to go to court to vindicate its policies and benefit the entire Nation[,] Congress must also ensure that they have the means to go to court, and to be effective once they get there."); id. at 33,314 (statement of Sen. Kennedy) (noting necessity of congressional action in enforcing civil rights).

107. See, e.g., Percival \& Miller, The Role of Attomey Fee Shifting in Public Interest Litigation, LAW \& ConTEMP. Probs., Winter 1984, at 233, 234-41 (discussing all public interest activities, including civil rights enforcement); Zemans, Fee Shifting and the Implementation of Public Policy, LAW \& CONTEMP. ProBs., Winter 1984, at 187, 199 (noting that more than personal benefit alone justifies vindication through civil rights litigation); Note, Promoting the Vindication of Civil Rights 
rights will likely be significantly under-enforced. The evidence in a society that only partially subsidizes civil rights enforcement supports the theoretical fears of under-enforcement. ${ }^{108}$

This conclusion should not be surprismg. While no citizen can be excluded from the benefits of a privately enforced civil right, public goods theory predicts that citizens will free-ride on the benefits provided by others. As noted earlier, ${ }^{109}$ the free-rider problem leads to underprovision of privately supplied public goods; consequently, private enforcement of civil rights will never reach a Pareto-efficient level.

Collective action, whether by local or national entities, therefore becomes necessary to prevent civil rights laws from becoming "mere liollow pronouncements." 110 To the extent that this Note has demonstrated civil riglits enforcement to be a public good, the "reasonable fee" requirement of section 1988 can be calculated from a traditional public goods perspective, with an eye toward constructing a definition leading to a Pareto-efficient level of enforcement.

\section{The Optimal Fee for Civil Rights Enforcement}

This part will design a method of determining a "reasonable" attorney's fee under section 1988 by using public goods analysis, eventually slowing that the fee should incorporate the attorney's opportunity costs of representing the civil riglits plaintiff. As discussed earlier, ${ }^{111}$ decentralized pricing systems fail to supply society's optimal amount of public goods; ${ }^{112}$ therefore, some central authority (here, presumably a court) must calculate a fee that will lead to the optimal provision of civil rights enforcement. ${ }^{113}$ However, to construct such a fee, one must be sensitive to the economic forces that keep a decentralized price system from pro-

Through the Attorney's Fees Awards Act, 80 CoLUM. L. Rev. 346, 349 (1980) (same). See generally Meltzer, Deterring Constitutional Violations by Law Enforcement Officials: Plaintifs and Defendants as Private Attorneys General, 88 CoLuM. L. Rev. 247 (1988) (discussing need for private attorneys general when party represents more interests than just his own).

108. See infra notes $91-92$ and accompanying text. Although the sources conflict, the weight of authority supports the proposition that civil rights are currently under-enforced.

109. See supra notes $40-41$ and accompanying text.

110. S. REP. No. 1011, supra note 26, at 6, reprinted in 1976 U.S. CODE CONG. \& ADMIN. News at 5913.

111. See supra notes 73-75 and accompanying text.

112. See Samuelson, Pure Theory, supra note 64, at 388-89 (optimal levels of collective consumption cannot be achieved through decentralized pricing system).

113. One solution proposed by Richard Musgrave, operating on the assumption that most public goods are "intermediate" in nature and lead to the production of private goods, is to calculate the market value of the private goods derived from the public good. See $1 \mathrm{R}$. MusGrave, Public FINANCE IN A DEMOCRATIC SOCIETY 62-63 (1986) (noting that better roads reduce individual automotive costs and trucking time). Unfortunately, the enforcement of civil rights rarely leads to the production of measurable private goods. 
viding the optimal level of a public good. The true obstacle to such an outcome is the problem of demand revelation. ${ }^{114}$ Consequently, the ideal attorney's fee is one that overcomes the problem of hidden demand without creating incentives to exaggerate deinand. ${ }^{115}$

\section{A. Fee Shifting as the Optimal Method for Civil Rights Enforcement}

It is overstating the problem of demand revelation to conclude that no method can be devised that measures consumer demand for a public good with reasonable accuracy. ${ }^{116}$ Edward Clarke proposes an analytically helpful inodel to ehicit accurate consumer preferences. Clarke argues that voters will truthfully reveal their preferences if each voter is convinced that her vote is the decisive vote on a project and that in no case will she be taxed an amount greater than her stated benefits. ${ }^{117}$ While Clarke's method suffers from its complexity and expense in a large-group setting, ${ }^{118}$ it adds insiglit into the problem. If a voter knows

114. See supra notes $80-81$ and accompanying text.

115. Demand will be overstated if all costs of preference revelation are removed. See D. STARRET, supra note 66 , at 69.

116. Eric Lindahl has argued that if two consumers bargain with each other and reach a consensus on the appropriate provision of a public good, an optimal level of that good will be supplied. See Lindahl, Just Taxation-A Positive Solution, in Classics IN THE THeORY OF Public Finance 168, 168-73 (R. Musgrave \& A. Peacock eds. 1967). Lindahl refined an earlier model developed by Kurt Wicksell, which suggested that an efficient level of public goods will be supplied if a contemplated public good project requires unanimous, or near unanimous, approval by the voting public. See Wicksell, A New Principle of Just Taxation, in Classics IN THE TheORY of Public FinanCE, supra, at 72, 90-94. Wicksell's theory is recognized as failing to deal with the immediate problem of this Note-the lack of incentive for voters to vote their true preferences. See generally J. HEAD, supra note 82, at 87-88 (discussing the model's limitations).

Although Lindahl's bargaining theory has been criticized by some as failing to elicit true demand preferences from consumers, see J. DUE \& A. FRIEDLAENDER, supra note 73, at 51-52, others have found that, if the bargaining group remains sufficiently small and free discussion is allowed, true preferences will be expressed and the good will be optimally supplied. See M. OLSEN, THE LoGic of COLlective Action: Public Goods AND THE THEORY OF Groups 53-57 (1971); van der Kragt, Orbell \& Dawes, supra note 75, at 113-14. Despite the merits of Lindahl's theory, the theory is of only limited usefulness in the context of a public good, such as a civil rights enforcement, which must be provided to a very large number of consumers. In large groups, the bargaining process breaks down. See id. at 119-20 (probability of unreasonable behavior increases as group size increases). There is also no guarantee that a large group will be able to organize into small bargaining units. See J. HEAD, supra note 57, at 88 (lack of motivation to signal individual public goods preferences cannot be overcome by "intersecting small-number agreements").

117. See E. ClARKE, supra note 75, at $72-75$ (employing example of public voting on pollution control project).

118. Clarke's model requires each voter to express in dollars their individual benefits from a given public goods project on a ballot. The stated benefits and detriments of all other voters are summed into "Yes/No" categories, excluding the voter under study. The stated dollar value of the individual voter's preference is then added to the aggregate of recorded benefits. If and only if that - incremental addition causes the project to exceed the dollar votes opposing the project will the voter be required to pay a small fixed tax plus a variable tax not to exceed the voter's stated benefit from the project. This process must be repeated for each voter. Id.; see also Clarke, Multipart Pricing of 
her stated preference will be decisive as to whether a good is supplied, and the voter knows that the cost of truthfully stating her preferences will always be less than or equal to the individual benefits received from such truthful statements, then the voter's stated demand for the public good will be accurate. ${ }^{119}$

If Clarke's voter preference model is accurate, it should be clear that prospective supply of civil rights enforcement by the federal government is bound to be suboptimal. The performance of the Enforcement Division of the Justice Department and the Legal Services Corporation (LSC), two government organizations deeply involved in civil rights enforcement, reinforces this prediction. Even absent the political disputes that are bound to disrupt these organizations, ${ }^{120}$ they face the intractable problem of calculating the public's demand for civil rights enforcement. Because of obstacles inherent in empirical measurement, debates eternally rage over the actual level of demand. ${ }^{121}$ Consequently, the Justice Department and the LSC face the arduous task of deciphering inaccurate voter preferences, attempting to construct a societal deinand function, and then supplying civil rights enforcement equal to that demand. All of

Public Goods: An Example, in Public Prices for Public Products 125, 125-26 (S. Mushlein ed. 1972) (outlining this process). Obviously, in the context of a national public good, such a process would be prohibitively expensive.

119. See E. ClarKe, supra note 75, at 73-75. For a brief mathematieal exposition of Clarke's theory, see R. CORNES \& T. SANDLER, supra note 68 , at 105-08.

120. See, e.g., Departments of Commerce, Justice, and State, the Judiciary, and Related Agencies Appropriations for 1989: Hearings Before a Subcomm. of the House Comm. on Appropriations, 100th Cong., 2d Sess. 817-18 (1988) (statement of Michael Wallace, Chairman, Regulations Committee, Legal Services Corporation) (acknowledging political battles within the LSC); Departments of Commerce, Justice, and State, the Judiciary, and Related Agencies Appropriations for 1988: Hearings Before a Subcomm. of the House Comm. on Appropriations, 100th Cong., 1st Sess. 306-07 (1987) (statement of Terry Roche, Exec. Dir., Legal Services of Southern Piedmont, citing The National Commitment to Civil Legal Services for the Poor, Legal Services Crises and Concerns, Feb. 1, 1987, at 1, col. 2, (discussing the political battles over LSC)); UNITED STATES COMM'N ON CIVIL RIGHTS, State of Civil Rights 1957 - 1983: THE Final Report of the U.S. CoMmission on CIVIL RIGHTS $71-76$ (1983) (criticizing various executive agencies, including Justice Department, for failure to coordinate and to take an aggressive role in civil rights enforcement); Englade, The LSC Under Siege, A.B.A. J., Dec. 1, 1987, at 66-73 (discussing political battles over control of the LSC).

121. Compare Mayhew, Institutions of Representation: Civil Justice and the Public, 9 LAW \& Soc'y REv. 401, $401-06$ (1975) (demand for public interest lawyers does not exceed supply) and Zemans, supra note 107, at 194 (same) with Departments of Commerce, Justice, State, the Judiciary, and Related Agencies Appropriations for Fiscal Year 1987: Hearings Before a Subcomm. of the Senate Comm. on Appropriations on H.R. 5161, 99th Cong., 2d Sess. pt. 2, at 1254-55 (statement of William Falsgraf, President, $\mathrm{ABA}$ ) (providing an estimated demand for public interest lawyers and showing demand to be well in excess of supply); B. Christensen, LAwyers For People of Moderate MEANS 21 (1970) (demand for public interest lawyers "virtually limitless"); B. CURRAN, THE LEGAL NEEDS OF THE PUBLIC 262 (1977) (persons who suffer civil rights violations generally fail to express demand for civil rights attorneys) and J. HANDLER, LAWYERS AND THE PURSUIT of LEGAL RIGHTS 92-99 (1978) (discussing and presenting evidence of minuscule percentage of pro bono hours devoted to civil rights cases). 
the previously discussed problems of ehcitimg true consumer preference make the appropriate level of civil rights enforcement by these agencies problematic, if not impossible.

The solution to the demand revelation problem for civil rights enforcement must combine Clarke's work on voter preferences with decentralized information gathering which does not rely on an agency's subjective determination of public preferences. ${ }^{122}$ Fee shifting synthesizes the benefits of eliciting truthful voter preferences and decentralized information, offering a mechanism that ensures an optimal level of civil rights enforcement desired across society, ${ }^{123}$

\section{Decentralized Information. A scheme of decentralized infor-} mation-gathering requires the government to determine the appropriate level of public goods supply based only on expressed and measured public demand. But the Justice Department and LSC predict the level of public demand for civil rights enforcement prospectively, based on limited information. A decentralized system, im comparison, operates retrospectively $\mathrm{m}$ response to expressed demand. Preferences are determmed first, and supply is subsequently financed. Because a decentrahized informational system requires that financing follow demand calculations, public goods are more efficiently financed after the fact by tax subsidies (or subsidized through price mcreases) rather tlian through prospective direct taxation. ${ }^{124}$ Consequently, a decentrahized approach to providing civil rights enforcement can be optimally implemented only by providing a subsidy through attorney fee shifting. Under a fee shifting regime, government (or a firm) incurs expenses by subsidizing legal services as they are required. Thus, the economic entity responds to, rather than predicts, demand.

122. D. STARRETT, supra note 66 , at 66 ("[A]ny individual who contracts for [public goods] automatically confers net benefits on others. ... So the private benefit from the purchase will differ from the social benefit; unless the contractor is appropriately altrustic, the contracted level will be incorrect from a social point of view. We seek a planning procedure that corrects for this distortion yet is still informationally decentralized.").

123. Many commentators have written on the subject of determining whether public laws should be enforced by a centralized public agency or by public subsidization of private, decentralized litigation. See, e.g., Landes \& Posner, The Private Enforcement of Law, 4 J. LEGAL STUD. 1, 15 (1975) (in a system where fines are awarded to private enforcers, the imposition of a higher penalty may send the wrong signal to private profit maximizers and lead to over-enforcement); Polinsky, Private Versus Public Enforcement of Fines, 9 J. LEGAL STUD. 105, 124 (1980) (private competitive enforcement leads to under-enforcement where external damage is high since it is optimal to deter most or all individuals). Although this Note does not attempt to resolve conclusively that debate, it will show that public subsidization of private enforcement is preferable when demand revelation is a problem.

124. See Roberts, Financing Public Goods, 95 J. Pol. EcoN. 420, 421-25 (1987) (arguing that, in most cases, the use of a tax subsidy is more efficient than direct taxation and provision). 
2. Correcting for Demand Revelation Distortions. Assuming that government-financed attorney fee shifting provides an accurate method of recording demand, the fee shifting scheme must also elicit accurate demand. Recall from Clarke's theory that a consumer will truthfully express his preferences if: (1) his expressions will determine whether the public good will ultimately be provided, and (2) the cost of his expression will always be less than or equal to the individual benefits he derives from such accurate expression. ${ }^{125}$ The first condition does not depend on the structure of the fee-shifting statute: a demand for civil rights enforcement (i.e., a decision to retain a lawyer and begin litigation) will almost always determine whether the right will be enforced. Fulfillment of the second condition, however, does depend on the amount of the fee award.

3. Arriving at the Proper Fee. Given the economic principles of public goods discussed above, it is now possible to calculate a "reasonable fee" that satisfies Clarke's conditions for accurate demand revelation for civil rights enforcement. Suppose Client retains Attorney under a pro bono arrangement to bring a section 1983 action to challenge a city regulation that allegedly infringes Client's freedom of speech. Should Client prevail, ${ }^{126}$ the court could enjoin the city from enforcing the regulation while awarding Client only a nominal amount of damages, say, five dollars. ${ }^{127}$ Clearly, to satisfy Clarke's conditions in these types of low-return circumstances, the cost to the "consumer" (the litigant and his attorney) of expressing his demand (bringing suit) must approach zero. ${ }^{128}$ The public goods literature confirms this proposition. ${ }^{129}$

The costs involved in expressing demand (i.e., instituting litigation) can be segregated into two components. First, the consumer faces the risk of not prevailing and hence bearing the entire cost of bringing suit. This cost has been the subject of much debate ${ }^{130}$ and will not substan-

125. See E. ClARKE, supra note 75 , at 73-74; Clarke, supra note 118, at 125-126; see also supra notes 117-19 and accompanying text.

126. See supra note 27 and accompanying text (discussing the prevailing party test).

127. See, e.g., Fox v. Parker, 626 F.2d 351, 352 (4th Cir. 1980) (award of five dollars).

128. Of course, the demand must reflect only legitimate civil rights claims. If the cost of expressing demand for imagined or baseless rights approaches zero, then enforcement will be over-provided. See infra notes 173-76 and accompanying text.

129. See J. DuE \& A. FRIEDlaENDER, supra note 73, at 60 (voter will express preference so long as tax burden not dependent on expression); D. STARRETT, supra note 69, at 69 (shifting cost of choosing to consumer leads consumer to understate demand).

130. See, e.g., Leubsdorf, supra note 14 (arguing that while attorney fees should be higher when the "plaintiff's lawyer will be paid only if his client succeeds than when he will be paid regardless of success, ... the contingency bonus should be prescribed for categories of cases and should reflect judgment about how much encouragement each category should receive"); Rowe, The Supreme Court on Attorney Fee Awards, 1985 and 1986 Terms: Economics, Ethics and Ex Ante Analysis, 1 Geo. J. LEGAL ETHICs 621, 632-34 (1988) (expressing support for Professor Leubsdorf's contin- 
tially affect our discussion since this Note is concerned only with finding a reasonable base fee. ${ }^{131}$ Second, and most significantly, the consumer bears the opportunity cost incurred when the attorney inust forgo other employinent. ${ }^{132}$ Thus, to keep the cost of accurately stating demand close to zero, the litigant not only must be protected against the risk of loss, but, when prevailing, inust also be compensated for the full costthe opportunity cost-of the litigation. While this approacl to cost presents a fundainental departure from Supreme Court case law, it is the standard approach in modern economic analysis. ${ }^{133}$

To depress the litigant's cost of accurately revealing demand for civil rights enforcennent close to zero, the fee awarded to prevailing parties must compensate the prevailing attorney for the lost opportunities of employment. Thus, when establishing the lodestar, ${ }^{134}$ the prevailing market rate should be set at what the attorney could have earned in the market had the attorney not taken time to enforce her client's civil rights. Such an approach will keep the consumer's cost of demand revelation near zero. Furthermore, local entities and the federal government will not be required to estimate prospectively what level of supply will inatch deinand: attorneys, for the most part, ${ }^{135}$ will be indifferent between enforcing civil rights and practicing in any other field of law, and accordingly will move freely between the fields as demanded. Because of this indifference, supply of civil rights attorneys will be virtually unrestricted. ${ }^{136}$ Thus, with

gency fee proposal, but noting the Supreme Court's "disingenuous and tendentious use" in Delaware Valley II of Professor Leubsdorf's analysis).

131. See supra note 16 (defining reasonable base fee).

132. This cost has been mentioned only in passing by courts: as one of the twelve Johnson factors, see Johnson v. Georgia Highway Express, Inc., 488 F.2d 714, 718 (5th Cir. 1974) (preclusion of other employment by the attorney due to acceptance of the case), and implicitly by Justice Brennan in Hensley v. Eckerhart, 461 U.S. 424, 447 (1983) (Brennan, J., dissenting in part, concurring in part) ("As nearly as possible, market standards should prevail, for that is the best way of ensuring that competent counsel will be available to all persons with bona fide civil rights claims.").

133. When two or more products are related through their production inputs, the cost of each product is always evaluated in terms of the amount of the other products forgone. See J. HENDERSON \& R. QUANDT, supra note 65, at 92-94 (joint products exist whenever quanities of two or more outputs are technically interdependent); D. SAPSFORD, LABOUR MARKET ECONOMICS 19 (1981) (price of non-market activity to worker, or earnings forgone by using hours or non-market rather than market activity, is opportunity cost). Thus, because antitrust representation and civil rights representation may be produced by the same input (attorney representation), the cost of each representation is most correctly determined with regard to the cost of the forgone representation.

134. See supra notes 29-39 and accompanying text (discussing lodestar/Johnson method).

135. See infra text following note 182 (discussing how the opportunity cost method will affect the choices of different types of attorneys).

136. Although the number of new lawyers entering the marketplace each year seems to be falling, see Vernon and Zimmer, The Size and Quality of the Law School Applicant Pool: 1982-1986 and Beyond, 1987 DUKE L.J. 204, 205, it is hard to imagine that demand for civil rights attorneys could exceed supply when attorney's are indifferent between civil rights and other types of practices. 
adequate supply and accurate expression of public demand, ${ }^{137}$ civil rights enforcement will be optimally provided. ${ }^{138}$.

4. Theory of Externalities as Verification of the Opportunity Cost Approach. Certam market failures, called externalities, are external diseconomies that impose a cost of producing a good on third parties. For example, when a steel manufacturer pollutes a nearby river by dumping its chemical waste there, it transfers much of the cost of waste disposal to the general public. Unless a tax is imposed to force the company to pay the cost of damages created by the pollution, it will lack market incentive to produce a public good (a pollution-free river) since the price of steel will not imclude certain real costs of production. Steel, offered at such an artifically low price, will be oversupplied. A carefully crafted tax "internalizes" the external cost from pollution and adjusts the price of steel appropriately. The tax shifts the cost of pollution onto the manufacturer and away from the public. Conversely, the environmental tax is also a mechanism to provide a public good-clean water-by eliminating the externality of pollution. The tax must be crafted to impose the cost of the pollution damage on the manufacturer but avoid overtaxing production of steel so as to raise steel prices to the point at which steel would be under-provided.

Clearly, there is an inverse relationship between externalities and public goods. In this case, the more clean water provided through taxation, the less pollution there will be. The inverse relationship between public goods and externalities ${ }^{139}$ is well known. ${ }^{140}$ In fact, civil rights enforcement can be analogously analyzed.

A civil rights infrigement constitutes an externality similar to environmental pollution. The costs of civil rights violations shift to the public in the form of restricted enjoyment of constitutional rights. This external diseconomy can be properly removed by taxing the civil rights violator (the government or local firm) an amount equal to the damage caused by tile violation. The appropriate civil rights tax is thus the level that equals the amount a person, $P$, suffering the violation would be will-

137. Demand for civil rights enforcement will never be perfectly revealed under any scheme. Ignorance of civil rights laws will always be a problem. If two-fifths of the population believe that people may be rightfully restrained from expressing unpopular opinions, see $\mathrm{H}$. MCCLOSKY \& A. Brill, Dimensions of Tolerance: What Americans Believe About Civil Liberties tbl. 2.1 (1983), many of those people likely would be unaware of civil rights violations.

138. See generally A. ATKINSON \& J. STIGLITZ, supra note 82, at 515 (stating that a mechanism patterned after Clarke's theory will create the dominant consumer strategy of accurate demand revelation and lead to Pareto efficiency).

139. R. CORNES \& T. SANDLER, supra note 68, at 29.

140. See P. JOHANSSON, supra note 65 , at 72 . 
ing to pay the violator to cease. ${ }^{141} P$ would be willing to pay no more than the costs imposed upon himself by the violation. Most costs imposed upon $P$ would fall under the category of substantive damages resulting from a civil rights violation, and thus are of no concern here. But the producer also imposes the cost of forcing $P$ to retain an attorney, $A$ ( $P$ and $A$ are collectively referred to here, as before, as the consumer) to enforce her rights. Thus, the producer imposes upon the consumer the cost of $A$ 's services-that is, the opportunity cost to $A$ of devoting time to enforcing $P$ 's civil rights. Consequently, $P$ and $A$ collectively would be willing to pay the producer up to the amount of substantive harm suffered by $P$ plus the opportunity costs of $A$ 's services. Thus, the equilibrium tax would include $A$ 's opportunity costs. ${ }^{142}$

Not surprisingly, the conditions for optimal production of goods that create externalities mirror the Samuelsonian conditions for optimal provision of public goods. ${ }^{143}$ Following from this inverse relationship, the equilibrium tax on an externality should equal the equilibrium price (attorney fee) for the inverse public good. Thus, the theory of proper taxation of externality-producing activities proves that the prevailing market rate factored into the lodestar should reflect the attorney's opportunity cost of devoting time to such enforcement.

\section{IMPLEMENTATION, JUSTIFICATION, AND IMPLICATIONS OF THE OPPORTUNITY COST METHOD}

This Note argued above that courts, in ordering a fee award under section 1988, should establish the lodestar by setting the prevailing market rate equal to the opportumity cost to the attorney of bringing the civil rights action. This part will develop the opportunity cost approach further and will determine whether such an approach is consistent with Congress's intent in enacting section 1988. Fimally, this part will analyze the real-world implications of such a change in fee awards.

141. Pigou first developed this approach, see A. PigoU, The Economics of Welfare, supra note 60 , at $183-88$, but it has been substantially refined, see, e.g., Cariton \& Loury, The Limitations of Pigouvian Taxes as a Long-Run Remedy for Externalities, 95 Q.J. EcoN. 559, 564 (1980) (arguing for additional lump sum tax); Cooter, The Cost of Coase, 11 J. LEGAL STUD. 1, 4-6 (1982).

142. See Baumol, On Taxation and the Control of Externalities, 62 AM. ECON. REv. June, 1972, at 307,311 (designing a tax to eliminate an externality and including consideration of opportunity costs); Cooter, supra note 141, at 5 .

143. R. CORnES \& T. SANDler, supra note 29, at 53 (equations 4 and 5); J. DAVIS \& J. HULETT, supra note 68, at 46; see also supra note 77 and accompanying text (discussing the Samuelson conditions). 


\section{A. Implementing the Opportunity Cost Approach in Attorney Fee Shifting}

Although this Note advocates a radical departure from current attorney fee shifting jurisprudence, it does share with Laffey v. Northwest Airlines, Inc. ${ }^{144}$ and the Save Our Cumberland Mountains, Inc. v. Hodel panel opimion ${ }^{145}$ a common mechanical approach in calculating a reasonable fee. In both of those cases, the D.C. Circuit looked first to the attorney's billing history in private representation and, if such history proved nonexistent, then resorted to a judicially crafted inarket rate. ${ }^{146}$ Implementing the opportunity cost standard in attorney fee shifting requires, however, a slightly different two-step process. Whereas Laffey requires courts to examine the attorney's billing history for similar work, ${ }^{147}$ the opportunity cost approach focuses on the billing history for dissimilar work. For example, if the attorney is normally a tax attorney, then the opportunity cost to the attorney of accepting a civil rights case is the amount she could have earned in her usual tax practice had she not accepted the civil rights case.

If the attorney is a full-time civil rights or public interest attorney and has no private billing history, then a proxy must be judicially developed by constructing an opportunity-cost-based market rate. This can be done empirically by calculating a set of market rates in a given coinmunity, reflecting experience, education, and other professional credentials. ${ }^{148}$ Consistent with the opportunity cost approach, such a judicially crafted market rate would be based on average rates for work other than civil rights hitigation. Of course, such a constructed fee would fail to account for many intangible factors (whether negative or positive) for each individual attorney, but no inanageable system can accurately measure such factors in the absence of a billing history.

Adnittedly, the opportunity cost method is a radical departure from established Supreme Court caselaw. In Blum v. Stenson, the Court specifically mandated that the prevailing market rate be based upon average rates charged for similar work. ${ }^{149}$ The Court has never backed away

144. 746 F.2d 4 (D.C. Cir. 1984), overruled, Save Our Cumberland Mountains, Inc. v. Hodel, 857 F.2d 1516 (D.C. Cir. 1988) (en banc).

145. Save Our Cumberland Mountains, Inc. v. Hodel, 826 F.2d 43 (D.C. Cir. 1987), rev'd, 857 F.2d 1516 (D.C. Cir. 1988) (en banc).

146. See Cumberland Mountains, 826 F.2d at 47-50; Laffey, 746 F.2d at 16 n.74.

147. See Laffey, 746 F.2d at 18.

148. For an example of this type of fee schedule, see Court Awarded Attorney Fees, supra note 35, at 260 n.70. To such a schedule should probably be added factors relating to academic performance and rates charged by comparable classmates.

149. 465 U.S. 886, 895-96 n.11 (1984); see also Save Our Cumberland Mountains, 857 F.2d at 1254 (recognizing the "similar services" requirement). 
from that approach. 150 Whether such a basic shift is justified by congressional intent is the subject of the next section.

\section{B. Congressional Intent}

An examination of the legislative history indicates that three concerns motivated Congress to enact section 1988. First, and most importantly, Congress desired to provide full and complete enforcement of the civil rights laws. ${ }^{151}$ Second, because Congress viewed civil rights to be at least as important as other statutory rights, it sought to put civil rights enforcement on the same footing as other statutory rights subject to fee shifting provisions. ${ }^{152}$ Fimally, Congress attempted to achieve the first two goals without granting windfalls in remuneration to civil rights attorneys. ${ }^{153}$ To that end, Congress himited fee awards to a "reasonable" amount.

The opportunity cost approach is consistent with these goals. A "reasonable" fee under section 1988 must reflect the opportunity cost of competent representation in order to provide for complete enforcement of civil rights: the opportumity cost regime helps cure the demand revelation problem and ensures that supply is always adequate to meet that demand.

Furthermore, the opportunity cost method certainly comes closer to elevating civil rights enforcement to the same level of importance as other statutory rights. Under the current "similar services" approach to calculating attorney fees, ${ }^{154}$ a civil rights fee award will be substantially

150. See, e.g., Missouri v. Jenkins, 109 S. Ct. 2463 (1989) (reaffirming the similar service approach).

151. See S. REP. No. 1011, supra note 26, at 6 (fee shifting needed because civil rights laws are not self-executing and are not to become "mere hollow pronouncements"), reprinted in 1976 U.S. Code Cong. \& Admin. News at 5913; 122 Cong. Rec. 33,313-14 (1976) (statements of Sens. Tunney and Kennedy); see also Berger, supra note 14, at 306, 310 ("the fundamental purpose of [fee shifting] provisions is to encourage full enforcement of the substantive rights to which they are attached").

152. See H.R. REP. No. 1558, supra note 26 , at 9 ("civil rights plaintiffs should not be singled out for different and less favorable treatment"); 122 CoNG. REC. 35,118 (1976) (statement of Rep. Seiberling) ("All we are trying to do in this bill is to provide for uniform treatment [of protecting civil rights with enforcing other interests such as antitrust] ...."); see also Berger, supra note 14, at 311 (legislative history indicates civil rights laws should be just as vigorously enforced as antitrust laws); cf. 122 CoNG. REC. 35,123 (1976) (statement of Rep. Drinan) (Congress has determined civil rights enforcement to be of "highest importance").

153. See S. REP. No. 1011, supra note 26, at 6 (fees should be adequate "but which do not produce windfalls to attorneys"), reprinted in 1976 U.S. CODE CoNG. \& ADMIN. NEwS at 5913; 122 CONG. REC. 33,314 (1976) (statement of Sen. Kennedy) (purpose of bill not to aid lawyers but to promote civil rights); $c f$. id. at 31,473 (statement of Sen. Allen) (expressing fears that the bill would "provide more bonanzas to the legal profession").

154. See supra note 147 and accompanying text (discussing Laffey). 
less than an antitrust fee award.155 An approach that results in such discrepancies effectively assigns relative priorities to statutory rights that have not been prioritized by Congress. ${ }^{156}$ Theoretically, the opportunity cost method would award to any attorney of comparable skill and credentials in the same legal market virtually identical hourly rates, whether the award be made in an antitrust, environmental, or civil rights case.

In addition, the opportunity cost method does not contravene Congress's desire to avoid conferring windfalls upon attorneys. Certainly, many public-spirited attorneys would receive higher fees than would have been minimally required to attract them to civil rights cases. However, if that were the only criterion for defining "windfall," the Supreme Court's decision in Blum would not be justified. In Blum, public interest lawyers, inspired to undertake civil rights representation for less than the market rate for such legal services, received market-rate awards. ${ }^{157}$ Arguably, those attorneys received windfalls. However, the legislative history of section 1988 indicates that Congress would not consider such an award a windfall. Rather, given Congress's two other expressed goals, a windfall involves an award that exceeds a level required to fully enforce civil rights laws. As this Note has argued, compensation on the basis of opportunity cost is required to ensure full enforcement of civil rights laws and such compensation does not, by definition, provide windfalls. ${ }^{158}$

A remaining question regarding congressional intent is whether the opportunity cost method offends the examples that Congress provided in the legislative history to shape reasonable fee awards. Congress provided four specific examples of cases in which the.fees awarded were adequate but not windfalls. ${ }^{159}$ Although some commentators might argue that the

155. See Berger, supra note 14, at 310-11 \& n.125 (discussing discrepancy in fee awards).

156. See id. at 311 ("the practical effect of awarding fees in private antitrust cases that are four to five times higher than those awarded in Title VII cases is to make private antitrust cases financially more attractive to the legal profession").

157. Blum v. Stenson 465 U.S. 886, 892-96 (1984); see also Missouri v. Jenkins, 109 S. Ct. 2463 (1989) (compensation for paralegals at rates above cost does not confer a windfall).

158. Windfalls arise from remuneration above that necessary to attract sufficient quantities of capital or labor inputs, not simply from compensation in a market where prices are generally inereasing. See infra notes $177-80$ and accompanying text (discussing the concept of economic rents). Suppose, for example, Factory $X$ advertises in a local newspaper that 100 positions are available at five dollars per hour. One hundred twenty people apply and 100 are hired at the five dollar hourly rate. Later, the price and demand for Factory X's product rises such that the company anticipates the need for 100 more workers. From the response to its previous advertisement, Faetory $\mathrm{X}$ knows that it must increase wages to attract 100 more workers. Thus, the first 100 employed will receive raises to reflect increasing labor costs even though the initial lower wage proved enough to attract them to work. Whenever demand for labor increases, the original workers generally will receive more than required to attract them. To label the raising of compensation a proscribed windfall would mean that supply of labor must remain static.

159. S. REP. No. 1011, supra note 26, at 6, reprinted in 1976 U.S. CoDE CONG. \& ADMIN. News at 5913 (citing Johnson v. Georgia Highway Express, Inc., 488 F.2d 714 (5th Cir. 1974); 
precedent established by those cases would preclude the use of an opportunity cost method to calculate attorney fees, a closer examination of the cases and Congress's intent in citing them indicates otherwise.

Two of the cases-Stanford Daily v. Zurcher ${ }^{160}$ and Johnson v. Georgia Highway Express, Inc. ${ }^{161}$-appear to be at odds on the issue of opportunity cost. The Stanford Daily court specifically stated that a securities lawyer should not receive his typical hourly rate when litigating a civil rights claim. ${ }^{162}$ The Johnson court, in comparison, held that one factor to be considered is the "otherwise available business" precluded by the representation in the case at hand. ${ }^{163}$ Significantly, Congress specifically sanctioned the Johnson factors but stated only that the court correctly applied certain of those factors in Stanford Daily. Johnson appears to accept as one factor, although not expressly, an opportunity cost method by considering otherwise available business. Stanford Daily, however, did not have to apply the opportunity cost factor to reach its conclusion; it simply considered and rejected the use of opportunity cost in dicta. ${ }^{164}$ Thus, one could argue that Stanford Daily's rejection of opportunity cost as a valid factor was not part of the holding that Congress sanctioned.

The Supreine Court, in Blanchard v. Bergeron, wrestled with another apparent inconsistency between Johnson and the three district court cases cited in the Senate Report, this time on the issue of a contingent fee agreeinent's effect on a section 1983 award. ${ }^{165}$ The Court held in favor of the position taken by the district courts, presumably because the issue of contingent fee agreenents was addressed in the holdings of the district court opinions and because that particular Johnson factor "standing alone, is not dispositive." 166 The Blanchard opinion, however, does little to resolve the issue of opportunity cost since only one district court addressed the problem in dicta while all three district courts addressed the contingent fee issue in their holdings.

While such hair-splitting is somewhat instructive on the issue of opportunity cost, placing too much reliance on inconsistent lower federal

Stanford Daily v. Zurcher, 64 F.R.D. 680 (N.D. Cal. 1974); Davis v. County of Los Angeles, 8 E.P.D. I 9444 (C.D. Cal. 1974); Swann v. Charlotte-Mecklenburg Bd. of Educ., 66 F.R.D. 483 (W.D.N.C. 1975)).

160. 64 F.R.D. 680 (N.D. Cal. 1974).

161. 488 F.2d 714 (5th Cir. 1974).

162. 64 F.R.D. at 684 .

163. 488 F.2d at 718.

164. See 64 F.R.D. at $684-85$.

165. 109 S. Ct. $939,943-44$, n.6 (1989) (discussing Swann v. Charlotte-Mecklenburg Bd. of Educ., 66 F.R.D. 483 (W.D. N.C. 1975); Davis v. County of Los Angeles, 8 Empl. Prac. Dec. (CCH) II 9444 (C.D. Cal. 1974); and Stanford Daily v. Zurcher, 64 F.R.D. 680 (N.D. Cal 1974)). 166. Blanchard, 109 S. Ct. at 944. 
court cases to justify a result contrary to the mandate of section 1988 proves dangerous. As Judge Starr stated in his Cumberland Mountains dissent, "It is, upon reflection, odd for the court to stake so much in the interpretive exercise on such a slender reed as case cites found in the bowels of secondary materials produced in the word processors of Capitol Hill."167 Justice Scalia, in his concurring opinion in Blanchard, echoed Judge Starr's reluctance to emphasize the lower court decisions cited in the Senate Report. In Justice Scalia's opinion, the majority's reference "to the citation of three District Court cases in a document issued by a single committee of a single house as the action of Congress displays the level of unreality that our unrestrained use of legislative history has attained." 168 One Congressman even noted that the standards sanctioned in the Committee Report are "evolving." 169 Thus, if section 1988 purports to provide full enforcement of civil rights, and full enforcement requires an opportunity cost model: for attorney compensation, then the passing reference to inconsistent cases in the legislative history should not stand in the way of adopting such a model.

\section{Real-World Implications}

This Note has maintained that a shift to an opportunity cost method of calculating a reasonable fee will result in the optimal supply of civil rights enforcement, since citizens will have an incentive to accurately state demand, and supply will be adequate to meet any such demand. This section focuses on whether certain real-world economic conditions will lead to inefficient enforcement or "rent-seeking behavior" 170 among attorneys under an opportunity cost regime. Although theoretically the opportunity cost method will be a Pareto-efficient improvement in civil rights enforcement, there is a risk that such improvement may not be "desirable" if there is a constraint on one of the Pareto-efficient conditions under the theory of "the second best."171 Two real-world considerations could impose such constraints, leading to the overprovision of civil

167. Save Our Cumberland Mountains, Inc. v. Hodel, 857 F.2d 1516, 1528 (D.C. Cir. 1988) (en banc) (Starr, J., dissenting).

168. Blanchard, $109 \mathrm{~S}$. Ct. at 947 (Scalia, J., concurring).

169. 122 CoNG. REC. 35,123 (1976) (statement of Rep. Drinan).

170. See infra notes $177-80$ and accompanying text (defining rents).

171. The theory of the second best states that "if there is introduced into a general equilibrium system a constraint which prevents the attainment of one of the Paretian conditions, the other Paretian conditions, although still attainable, are, in general, no longer desirable." Lipsey \& Lancaster, The General Theory of Second Best, 24 REv. Econ. STUD. 11, 11 (1956). In other words, there is a real danger in "piecemeal planning" that ignores the strategic behavior on the part of citizens and attorneys and its effect on the Paretian improvement discussed in this Note. See I. LITTLE, A CR1TIQUE OF WeLFARE ECONOMICS 89 (1950) (discussing how "piecemeal" or "utopian" planning ignores the effects of a Paretian improvement on income distribution). However, while the theory of 
rights enforcement: (1) whether the opportunity cost method allows litigants to bear so little of the cost of bringing suit that their denıand for civil rights enforcement will exceed the Pareto-efficient level, and (2) whether rent-seeking behavior on the part of attorneys will lead to artificially inflated opportunity costs.

1. Non-optimal Demand for Enforcement. Enforcenent of civil rights is expensive. ${ }^{172}$ If consuniers of civil riglits enforcenient do not liave to bear the cost of successfully vindicating important social rights, but also face no costs of vindicating extremely trivial, inıagined, or baseless rights, then the consunier is likely to exaggerate his demand. ${ }^{173}$

The structure of our civil riglits laws, lowever, in conjunction witl the "prevailing party" requirement, safeguards against such excess demand. For example, freedom of speech jurisprudence has evolved to the point where courts balance the public interest in free and open speecl with the public interest in an orderly society. ${ }^{174}$ Consequently, a party prevails only when he can show that the public interest in free speecl sufficiently outweighs the interest in social order. If the party fails, he then bears the cost of his own attorney's fees; if the suit is found frivolous, he bears some of the costs of the opposing party. ${ }^{175}$ Thus, the party is required to assess the merits of his case and the social cost of bringing the case, ${ }^{176}$ and therefore will rationally bring only those cases that have

the second best requires us to "proceed cautiously," it does not require paralysis. Misham, Second Thoughts on Second Best, 14 OXFORD ECON. PAPERS (n.s.) 205, 216 (1962).

172. See, e.g., City of Riverside v. Rivera, 477 U.S. 561,581 (1986) (prevailing party awarded $\$ 33,350$ in damages and attorneys fees of $\$ 245,456$ ).

Assuming that the dollars dedicated to enforcing a civil right is a private good, then one can say that the RPT, see supra note 77 and aecompanying text for definition, of the private good for the public good increases as more rights are enforced.

173. This implies that the RPT is greater than the MRS. As each enforced right becomes increasingly trivial, the public interest in abridging that right increases; thus the public is more willing to substitute infringement of rights for protection of those trivial rights. Therefore, the MRS of the public interest in "abridging" compared to the public interest in "protecting" will decrease.

174. See, e.g., Dennis v. United States, 341 U.S. 494, 506-09 (1951) ("Overthrow of the Government by force and violence is certainly a substantial enough interest for the Government to limit speech."); Schenck v. United States, 249 U.S. 47, 52 (1919) (free speech does not protect a man from falsely shouting fire in a theatre). See generally Hart, Utilitarianism and Natural Rights, 53 TUL. L. REv. 663, 673-80 (1979) (discussing the clash between utilitarianism and rights philosophies that gave rise to the current state of civil rights jurisprudence); A. OKUN, EQUALITY AND EFFICIENCY: The Big Tradeoff 6-9 (1975) (same); R. POSNer, The Economics of Justice 48-51 (1983) (same).

175. See Roper v. Edwards, 815 F.2d 1474, 1478 (11th Cir. 1987) (finding civil rights claim frivolous and awarding fees to defendant); Ellis v. Cassidy, 625 F.2d 227, 230 (9th Cir. 1980) (same). Thus the party must weigh both the MRS and the RPT. A rational consumer will seek enforcement to the point where the MRS equals the RPT-the Pareto-efficient level of enforcement.

176. See supra note $\mathbf{1 7 5}$ and accompanying text (discussing Pareto efficiency). 
some chance of success-a result that Congress likely would find desirable.

2. Rent-Seeking Behavior by Attorneys. Critics of the opportunity cost method will be quick to point out that rational civil rights attorneys will attempt to shift their practices into the highest-paying areas of the legal profession, leading to artificially inflated attorneys' fees awards and a decreased level of expertise among most civil rights attorneys. This criticism, however, makes a crucial assumption-that paying attorneys' opportunity costs will drive fee awards up, and that the upward movement is per se inefficient. At some point, obviously, a fee award will be too high, but any upward movement in awards is not necessarily bad for society. An examination of when a fee award is too high reveals that fee awards based accurately on opportunity costs can never be high enough to be inefficient.

When is a fee award too high? Economists have responded to this type of question with the concept of economic rent. To economists, a resource owner is paid too much (receives a "rent") for his resource only if the payment exceeds the owner's next best alternative use, i.e., the owner's opportunity cost. ${ }^{177}$ Rents can positively affect society by stimulating entrepreneurial decisions, ${ }^{178}$ but the existence of rent indicates a loss of social welfare through inefficient resource allocation (monopoly rents) ${ }^{179}$ and through resources spent in the pursuit of that rent. ${ }^{180}$ Yet, so long as the resource owner is paid his opportunity cost, rents-by definition-will not arise.

The extension of economic rent analysis to civil rights enforcement can best be illustrated with an example. If $X$, a tax attorney, is paid $\$ 200$ per hour on average, the market has presumably determined that $X$ 's services are worth that amount. If $X$ spends five hours on a civil rights case, $X$ 's opportunity cost equals $\$ 1000$. Society loses $\$ 1000$ in services in the tax field, but gains at least $\$ 1000$ in the area of civil rights. ${ }^{181}$ Thus, granting $X$ an award of $\$ 1000$ in a civil rights case does not confer a rent on $X$, because he receives only his opportunity cost, and society

177. See Tollison, Rent Seeking: A Survey, 35 KyKLos 575, 577 (1982).

178. $I d$.

179. Id. at 576.

180. For example, lobbying expenses and expenses of transferring resources to rent-conferring activities constitute such waste. See generally Krueger, The Political Economy of the Rent-Seeking Society, 64 AM. Econ. REv., June 1974, at 291, 291-303 (discussing substantial deadweight costs of rent-seeking behavior in the granting of international trade licenses); Tollison, supra note 177, at 575-82 (discussing wastefulness of resources spent in pursuit of transfers).

181. The gain is at least $\$ 1000$ because of the congressionally determined preeminence of civil rights, as opposed to economic rights, in our society. See supra note 152. 
does not suffer a loss in welfare from inefficient allocation of legal resources.

Suppose now that $X$ is a full-time public interest attorney. Critics might suggest that $X$ could take a few tax or securities cases per year and use those cases to inflate his opportunity cost. Realistically, the criticism fails because no attorney can build a successful practice in any area by taking a few isolated cases per year. The public interest attorney who takes on a small tax client with the intent of inflating his billing rate for later fee shifting probably will not accomphish his goal. Techmically, however, even if the attorney could take one case per year and charge a high rate for that case, that high rate still properly reflects his opportunity cost. A fee award based on that opportunity cost does not, by definition, confer an econonic rent. ${ }^{182}$ Rather, opportunity cost fee awards more accurately reflect the value of civil rights enforcement and thus would lead to a more efficient allocation of resources.

Arguably, awarding an attorney's opportunity cost also could lead to "dabbling" in civil rights litigation by high-priced lawyers and a decrease in the overall expertise of civil rights attorneys. A simple example proves otherwise, however. Suppose attorneys $A, B$, and $C$ are of identical age and have the same educational credentials and length of experience. Suppose also $A$ is a full-tinie public interest lawyer who places a positive value on representing civil rights claimants such that he would be indifferent between representing a civil rights plaintiff for $\$ 50$ per hour and any other client for $\$ 100$ per hour. $B$ specializes in commercial litigation and is indifferent between representing a civil rights plaintiff for $\$ 90$ per hour and any other client for $\$ 100$ per hour. Thus, $B$ rarely represents civil rights plaintiffs-usually only when his conscience gets the better of him. $C$ specializes in securities hitigation and charges a very high fee. $C$ places no positive or negative value on representing civil rights plaintiffs and thus never undertakes such representation.

Under the present method of determining reasonable fees, only $A$ will specialize im civil rights laws, while $B$ will only "dabble" in the area, and $C$ will obtain no exposure to the area. Under an opportunity cost model, $A$ will still specialize (and will be better paid) in civil rights representation, and $B$ will greatly increase his civil rights caseload, and night even specialize in civil rights if lis market composite rate would be $\$ 90$ or higher. $C$, wanting to maintain his securities litigation practice and billable hours, will undertake an occasional civil rights case. Thus, in this situation, the general argument that an opportunity cost standard

182. Significantly, rents would most likely arise in those situations in which Congress attempts to fix by statute a reasonable fee-say $\$ 100$. In that case, attorneys with low opportunity costs could collect rents on their services. 
would reduce overall expertise is not persuasive. Many attorneys who place a premium on representing civil rights plaintiffs, or whose billing rates are close to their market composite rates, would be coaxed into speciahizing in civil rights higation. Thus, the number of new dabblers could well be offset or surpassed by the number of new specialists.

\section{Fairness to the Defendant}

Critics of the opportunity cost method surely will argue that this method is unfair to the defendant. Why should defendant $X$ pay $\$ 200$ per hour in fee awards while defendant $Y$ pays only $\$ 100$ simply because $X$ is opposed by a tax attorney while $Y$ is opposed by a full-time public interest attorney? A completely satisfactory answer for such critics probably does not exist. The lack of such a satisfactory answer, however, has not prevented such developments in analogous situations. In the law of torts:

[I]f a person fires [a gun] across a road when it is dangerous to do so and kills a man who is in receipt of a large income, he will be liable for the whole damage, however great, that may have resulted to his family, and cannot set up that he could not have reasonably expected to have injured any one but a labourer. ${ }^{183}$

Such imconsistencies seem incongruous with the goal of deterrence because defendants cannot properly gauge the riskiness of their conduct. Furthermore, the result is disturbing to the extent that tort law places a value on a life, or an opportunity-cost system creates a penalty for a wrong, based wholly on fortuitous circumstances. Yet, tort law's emphasis on complete compensation for injuries has supported the use of an opportunity cost method of calculating damages: what would the survivor's income have been had the decedent's resources been put to the best alternative use (i.e., lost earnings)? Likewise in the area of civil rights, Congress has mandated the complete enforcement of civil rights laws. Consequently, we must live with the tensions between the mandate of complete enforcement and the goal of deterrence.

\section{CONCLUSION}

Reasonable-fee jurisprudence needs improvement and clarification. With satellite litigation over fee awards absorbing significant judicial resources, future congressional reform of fee shifting in civil rights cases is desirable to inject expressly the theory of opportunity cost into calculating reasonable fees for prevailing parties. This Note has shown, however,

183. Smith v. London \& South Western Ry., 6 L.R.-C.P. 14, $22-23$ (1870 (Blackburn, J.); see also Kubista v. Romaine, 14 Wash. App. 58, 62-63, 538 P.2d 812, 815 (1975) (lost earning capacity always part of tort damages). 
that absent such reform, courts could take a systematic, public-goods approach to the problem consistent with congressional intent. The enforcement of civil rights is a public good, and, if recognized as such, a method of calculating reasonable fees arises from a relatively simple public goods analysis.

A court adopting the opportunity costs approach used in this Note would necessarily depart from established reasonable-fee caselaw. Courts currently use typical market rates for similar attorneys doing similar work. This Note advocates the use of rates established by the attorney's opportunity cost of taking the civil rights case. The fee award should reflect the rate that the attorney would have been able to charge in her normal area of expertise-in areas other than civil rights. A fee award based on the attorney's opportunity cost will result in accurate expression of deinand for civil rights enforcement and an adequate supply of civil rights attorneys to meet that demand.

William R. Mureiko 